\title{
Epigenetic chromatin modifiers in barley: IV. The study of barley Polycomb group (PcG) genes during seed development and in response to external ABA
}

\author{
Aliki Kapazoglou', Alessandro Tondelli2, Dimitra Papaefthimiou', Helen Ampatzidou', Enrico Francia3, \\ Michele A Stanca ${ }^{2}$, Konstantinos Bladenopoulos ${ }^{4}$ and Athanasios S Tsaftaris ${ }^{* 1,5}$
}

\begin{abstract}
Background: Epigenetic phenomena have been associated with the regulation of active and silent chromatin states achieved by modifications of chromatin structure through DNA methylation, and histone post-translational modifications. The latter is accomplished, in part, through the action of PcG (Polycomb group) protein complexes which methylate nucleosomal histone tails at specific sites, ultimately leading to chromatin compaction and gene silencing. Different PCG complex variants operating during different developmental stages have been described in plants. In particular, the so-called FIE/MEA/FIS2 complex governs the expression of genes important in embryo and endosperm development in Arabidopsis. In our effort to understand the epigenetic mechanisms regulating seed development in barley (Hordeum vulgare), an agronomically important monocot plant cultivated for its endosperm, we set out to characterize the genes encoding barley PcG proteins.

Results: Four barley PCG gene homologues, named HVFIE, HvE(Z), HvSu(z) 12a, and HvSu(z) 12b were identified and structurally and phylogenetically characterized. The corresponding genes HvFIE, HvE(Z), HvSu(z)12a, and HvSu(z)12b were mapped onto barley chromosomes $7 \mathrm{H}, 4 \mathrm{H}, 2 \mathrm{H}$ and $5 \mathrm{H}$, respectively. Expression analysis of the $P c G$ genes revealed significant differences in gene expression among tissues and seed developmental stages and between barley cultivars with varying seed size. Furthermore, HvFIE and $H_{V} E(Z)$ gene expression was responsive to the abiotic stress-related hormone abscisic acid (ABA) known to be involved in seed maturation, dormancy and germination.

Conclusion: This study reports the first characterization of the PCG homologues, HvFIE, HvE(Z), HvSu(z)12a and $\mathrm{HvSu}(z) 12 b$ in barley. All genes co-localized with known chromosomal regions responsible for malting quality related traits, suggesting that they might be used for developing molecular markers to be applied in marker assisted selection. The PCG differential expression pattern in different tissues and seed developmental stages as well as in two barley cultivars with different seed size is suggestive of a role for these genes in barley seed development. HvFIE and HvE(Z) were also found to be induced by the plant hormone ABA implying an association with ABA-mediated processes during seed development, germination and stress response.
\end{abstract}

\section{Background}

Epigenetic regulation of gene expression plays a central role in eukaryotic development and takes place through modulation of chromatin structure. Highly organized chromatin consisting of DNA wrapped around histone

\footnotetext{
* Correspondence: tsaft@certh.gr

1 Institute of Agrobiotechnology, CERTH, Thermi-Thessaloniki, GR-57001, Greece

Full list of author information is available at the end of the article
}

proteins in nucleosomal structures can switch between relaxed and condensed states associated with transcriptional activity and transcriptional repression, respectively [1]. This is accomplished though cytosine methylation of DNA and post-translational modifications of nucleosomal histone tails. Histone modifications include changes in methylation, acetylation, and phosphorylation on specific lysines and arginines residues. Generally 
methylation of histone 3 on lysine 9 and 27 (H3K9, H3K27) leads to a repressive chromatin state correlating with gene silencing whereas methylation of histone 3 on lysine 4 (H3K4) leads to a permissive chromatin state correlating with gene activation [2]. Histone acetylation and deacetylation result in active and silent chromatin forms, respectively [3]. This kind of epigenetic regulation operates on various aspects of plant growth and development, including seed formation and stress responses (reviewed in $[4,5])$.

In flowering plants, the seed is formed through the process of double fertilization. Fertilization of the egg cell by a sperm cell from the male gametophyte generates the diploid embryo from which the organs, tissues and shoot meristems of the plant will be generated. Fertilization of the adjacent central cell by a second sperm cell forms a triploid endosperm, in angiosperms, which supports embryo growth and development by producing storage proteins, lipids, and starch [6].

Bypass of double fertilization is observed in natural apomicts or after mutagenesis of specific gene loci. In Arabidopsis mutations of the FIS (Fertilization Independent Seed) class of genes: FERTILIZATION INDEPENDENT SEED (FIE), MEDEA (MEA), FERTILIZATION INDEPENDENT SEED2 (FIS2), MULTICOPY SUPRESSOR OF IRA1 (MSI1) and BORGIA (BGA), result in the formation of seed-like structures in the absence of double fertilization that eventually collapse [7-9]. The phenotype of fie, mea, fis 2 and msi1 mutants is accompanied by another impressive characteristic, that is, endosperm overproliferation $[9,10]$. Endosperm overproduction and seed size increases are also observed in crosses where extra paternal genomes or hypomethylated maternal genomes are used [11]. Another feature of the fis phenotype is that when the female gametophyte carrying a mutation in a fis locus is fertilized by a wild type plant, the seed finally collapses indicative of a lethal maternal effect of the fis mutation and a gametophytic maternal control over seed development by FIS genes $[7,8]$. This is partially attributed to parental imprinting of FIE, MEA and FIS2 where only the maternal allele is expressed during the early stages of seed development [12-14].

The common phenotypic effects of the fis mutants are explained by the shared function of the FIS proteins in a PcG complex. The participation of these proteins in a PcG complex was first proposed by [10] and it is now well established that FIE, MEA, FIS2 and MSI1 form the so called FIE/MEA complex, one of the three PRC2 (Polycomb Repression Complex 2) homologues in Arabidopsis, regulating seed formation [15].

The PRC2 complex also known as EXTRA SEX COMBS-ENHANCER OF ZESTE (ESC-E(Z)) complex is one of three PcG complexes in Drosophila. PRC2 has been shown to play a role in the epigenetic silencing of target genes involved in cell growth and proliferation and in early development both in Drosophila and mammals. Its function involves $\mathrm{H} 3 \mathrm{~K} 27$ methyltransferase activity [16]. Methylation of lysines 9 and 27 of histone 3 serve as epigenetic marks of transcriptional silent loci. The PcG/ PRC2 complex in Drosophila contains four essential subunits: two WD40 proteins, named EXTRA SEX COMBS (ESC), and P55 containing the WD40 domain involved in protein-protein interactions, a zinc finger protein, SUPRESSOR OF ZESTE 12 [Su(z)12], and a SET-domain protein responsible for methyltransferase activity, ENHANCER OF ZESTE E(Z) [E(Z)] $[17,18]$.

Different variants of the PRC2 complex have been identified in plants depending on developmental stage, the best studied one being the FIE/MEA complex which regulates the initiation of seed development [18]. It consists of FIE, MEA, FIS2 and MSI1, which are homologous to the Drosophila ESC, E(Z), $\mathrm{Su}(\mathrm{z}) 12$, and $\mathrm{P} 55$, respectively [19,20,13,10]. In Arabidopsis all PcG complexes are predicted to contain the FIE and MSI1 subunits. Depending on cell type and function the different PcG complexes contain one of the three homologues of the Drosophila EZ protein, MEA, CURLY LEAF (CLF) or SWINGER $(\mathrm{SWN})$, and one of the three homologues of the Drosophila $\mathrm{Su}(\mathrm{z}) 12$ protein, EMBRYONIC FLOWER 2 (EMF2), FERTILIZATION INDEPENDENT SEED 2 (FIS2), and VERNALIZATION2 (VRN2), respectively. The EMF2CLF/SWN-FIE-MSI1 complex has been suggested to play a role in suppressing the transition from vegetative development to flowering and flower organ formation $[15,21]$ and the VRN2-CLF/SWN-FIE-MSI1 has been implicated in the regulation of the process of vernalization $[15,22,23]$. EMF2, FIS2 and VRN2, the three Su(z)12-like proteins in Arabidopsis, contain a classical $\mathrm{C}_{2} \mathrm{H}_{2}$ zinc finger similar to the fingers found in sequence-specific DNA-binding proteins and another stretch of amino acids, located $\mathrm{C}$-terminal to the zinc finger, that is conserved between $\mathrm{DsSu}(\mathrm{z}) 12, \mathrm{HsSu}(\mathrm{z}) 12, \mathrm{EMF} 2, \mathrm{VRN} 2$ and FIS2 and has been termed VEFS box (VRN2-EMF2FIS2-Su(z)12 box) [24].

Homologues of the PcG proteins of the FIE-E(Z) complex have been identified in other plant species including monocots, indicating their involvement in a conserved regulatory mechanism among all higher plants [17].

Three target genes for the Arabidopsis FIS2-FIE-MEAMSI1 complex operating in seed development have been identified so far. The first one is PHERES1(PHE1), a type I MADS box gene [25] which is parentally imprinted in the developing seed, with the maternal allele being silenced and the paternal allele expressed in specialized endosperm cells during the first two days after fertilization [26,27]. The second target is the $M E A$ gene itself, demonstrating an autoregulating mechanism for the imprinting of a PcG epigenetic silencer [28,29]. The third 
one is FUS3, a transcription factor belonging to the plantexclusive B3 domain TF family, specifically expressed in seeds during the seed filling phase [30].

Seed development, dormancy and germination are under the control of plant hormones, in particular ABA and gibberellic acid (GA). ABA inhibits germination and is required for the acquisition of dessication tolerance and entry into seed dormancy acting antagonistically to GA during these processes [31,32]. It is also involved in various aspects of plant growth and development including abiotic stress tolerance. Histone modifications have been suggested to play a major role in ABA-mediated processes such as seed development, germination and abiotic stress adaptation [4]. For example, in leaves of Phaseolus vulgaris, externally supplied ABA has been shown to induce methylation of $\mathrm{H} 3 \mathrm{~K} 4$ and acetylation of H3K14 and H4K5 (indicative of gene activation) of a chromatin region around the phaseolin promoter, and ectopic expression of the otherwise silent in leaves phaseolin gene (encoding a major seed storage protein) [33]. Likewise, ABA-treated seeds of an Arabidopsis mutantof PICKLE (a chromatin remodelling factor mediating suppression of embryonic identity upon germination) showed high expression levels of the ABA-induced transcription factors, ABI3 and ABI5, involved in seed filling. This correlated with reduced H3K9 and H3K27 methylation at ABI3 and ABI5 promoters, in the ABA treated mutant seeds than in wild type seeds [34]. In another study, ABA treatment caused severe reduction in expression of the Arabidopsis histone deacetylase gene, $A t H D 2 C$, whereas overexpression of $A t H D 2 C$ resulted in enhanced abiotic stress tolerance and both repression or induction of several ABA-responsive genes [35]. Recently, ABA was suggested to be a positive regulator of SWI3B, a subunit of the chromatin remodelling complex SWI/SNF, as in Arabidopsis swi3b mutant seedlings exposed to external $\mathrm{ABA}$ there was reduced expression of ABAresponsive genes [36]. Furthermore, $\mathrm{ABA}$ or an $\mathrm{ABA}$ signal was suggested to affect epigenetic states, the DNA replication machinery and chromatin mediated gene expression in Arabidopsis seedlings [37].

Despite the extensive studies on epigenetic regulation of seed development in Arabidopsis, knowledge on epigenetic regulation through DNA and chromatin modulation in cereal seed development is only now starting to emerge. The expression of a large number of genes encoding structural proteins, metabolic enzymes, transcription factors and DNA and chromatin modulators during seed development and germination has been investigated in barley, through large-scale transcriptome analysis [38]. Very recently, as part of our efforts to study epigenetic control mechanisms during seed development in barley, we isolated members of the two families of histone deacetylases, the plant specific HD2 family and the
RPD3/HDA1 family as well as members of the histone acetyltransferase families, GCN5, MYST, ELP3, respectively, and investigated their expression at different seed developmental stages, in different grain-size cultivars and in response to external hormonal stimuli [39-41].

Considering the economic importance of cereal crops such as barley, rice, wheat and maize, we report here the characterization of the barley PcG gene homologues. More specifically, a FIE homologue, termed HvFIE, an $E(Z)$ homologue, termed $H v E(Z)$, and two $\operatorname{Su}(z) 12$-like homologues, termed $\mathrm{HvSu}(z) 12 a$ and $\mathrm{HvSu}(z) 12 b$, respectively, were characterized. The mapping position of $H \nu F I E, H \nu E(Z), H \nu S u(z) 12 a$, and $H v S u(z) 12 b$ on different barley chromosomes was assigned, and their expression was examined in different tissues and seed developmental stages and in barley cultivars which differ in seed size and weight. Furthermore, the expression of $H v F I E, H v E(Z)$ and $\mathrm{HvSu}(z) 12 b$ was investigated after treatment with the plant hormone $\mathrm{ABA}$, a modulator of gene expression during developmental and environmental changes, operating often through epigenetic modifications of target genes.

\section{Methods}

\section{Plant material}

Commercial barley cultivars, Caresse, Carina and Ippolytos, differing in seed size and weight were planted in the field and were the source of RNA for expression analysis. For Caresse, the weight of 1000 grains is $50-55 \mathrm{gr}$, and $98 \%$ of seeds have diameter longer than $2.5 \mathrm{~mm}$, for Carina the weight of 1000 grains is $36-40$ gr and $60-65 \%$ of seeds have diameter longer than $2.5 \mathrm{~mm}$ whereas for Ippolytos, seeds weigh 25-31 gr per 1000 grains and only $35-45 \%$ of seeds have diameter longer than $2.5 \mathrm{~mm}$ http:/ /www.cerealinstitute.gr. The Oregon Wolfe Barley Dominant (OWB-D), Oregon Wolfe Barley Recessive (OWBR), L94 and Vada parental barley lines were used for polymorphism detection and mapping.

\section{Hormonal treatment}

Seven-day-old seedlings (Caresse) grown in a growth chamber $\left(16\right.$ hours $(\mathrm{h})$ light, $8 \mathrm{~h}$ darkness, at $\left.22^{\circ} \mathrm{C}\right)$ were sprayed with $100 \mu \mathrm{M} \mathrm{ABA}$, (abscisic acid +/- cis, transABA, SIGMA). Aerial parts of plants were collected at $6 \mathrm{~h}$ and $24 \mathrm{~h}$ after treatment and immediately stored in liquid nitrogen. Aerial parts from five plants were pooled together for RNA extraction for each time point. Control plants were sprayed with water plus $0.2 \%$ Tween.

\section{Identification of barley PcG gene homologues and protein analysis}

The barley FIE and $E(Z)$ homologues were identified by searching the barley EST database at the TIGR Web site http://www.tigr.org. Blast searches were performed using the complete cDNA sequence of Arabidopsis FIE, MEA, 
FIS2. Two tentative consensus sequences of barley ESTs in the TIGR web site, TC134355 and TC140937, were identified, coding for genes which are homologous to the Arabidopsis FIE and MEA, respectively. A blastn search on the NCBI Web site http://blast.ncbi.nlm.nih.gov/ Blast.cgi using TC140937 identified a full length $E(Z)$ mRNA sequence (AK251149) from the BARLEY DB http://www.shigen.nig.ac.jp/barley/. Three complete mRNA sequences encoding $\mathrm{Su}(z) 12$-like homologues were identified in GenBank with accession numbers AB085817, AB085818, AB085819, respectively. Homology searches were performed with a BLAST algorithm [42] against the DDBJ/EMBL/GenBank database. Sequence alignments were generated with the Clustal W Method [43] of MegAlign (LaserGene software) and processed with the Bioedit software. The sequences and accession numbers used for protein sequence analysis are shown in Table 1. The phylogenetic tree was calculated using MEGA 3.1 software [44] by the Neighbor-Joining Method with p-distance correction [45]. For $E(Z)$, the Bayesian inference of phylogeny was applied with the use of MrBayes 3.1.2 [46]. Four Metropolis-coupled Markov chain Monte Carlo chains were run on one million generations, with sampling every 100 generations. After discarding the first 5,000 unstable trees as burn-in, a majority-rule consensus tree was visualized and edited with TreeView 1.6.6 [47].

\section{Mapping of barley PcG genes}

Genomic DNAs extracted from 94 'OWB-Dominant' $x$ 'OWB-Recessive' [48] doubled haploid lines and from 103 'L94' x 'Vada' [49] recombinant inbred lines were used for linkage analyses. Specific PCR primer pairs were designed based on the nucleotide sequences of the $P c G$ genes by using the software Primer3 [50] (Table 2). PCR amplifications were performed in a $20 \mu \mathrm{l}$ final volume containing: $40 \mathrm{ng}$ of genomic DNA as template, $1 \times$ Promega PCR buffer, $1.5 \mathrm{mM}$ of $\mathrm{MgCl}_{2}, 5 \%$ DMSO, $0.25 \mathrm{mM}$ of each dNTP, $0.4 \mu \mathrm{M}$ of each primer, and $1 \mathrm{U}$ of Taq DNA Polymerase (Promega, Madison USA). Reactions were incubated for $2 \mathrm{~min}$ at $94^{\circ} \mathrm{C}$, followed by 40 cycles of $94^{\circ} \mathrm{C}$ for $30 \mathrm{~s}, 55^{\circ} \mathrm{C}$ for $30 \mathrm{~s}, 72^{\circ} \mathrm{C}$ for $1 \mathrm{~min}$, and a final extension of $72^{\circ} \mathrm{C}$ for $7 \mathrm{~min}$. PCR products were purified using the Wizard SV Gel and PCR Clean-Up System (Promega, Madison USA), and sequenced on both strands to confirm their identities, then sequences were aligned using the Staden package http://staden.sourceforge.net to identify Single Nucleotide Polymorphisms (SNPs). Inspection of the restriction enzyme cleavage sites with the software WebCutter http://www.firstmarket.com/cutter) revealed HindIII and DdeI restriction enzyme cleavage polymorphisms in the sequenced $H v E(Z)$ and $H v S u(z) 12 a$ PCR products, respectively. For $H v S u(z) 12 b$ and $H v F I E$ sequence polymorphisms identi- fied between the mapping parents were not within restriction sites, so PCR markers were made by introducing a restriction site (RsaI and $D d e \mathrm{I}$, respectively) into the PCR product using the dCAPS strategy [51]. According to manufacturer's instructions, $5 \mu \mathrm{l}$ of PCR product were incubated for $1.5 \mathrm{~h}$ with $1 \mathrm{U}$ of the corresponding restriction enzyme, $1 \times$ reaction buffer and $0.1 \mathrm{mg} / \mathrm{ml}$ of bovine serum albumin, and then separated on a standard $2 \%$ agarose gel. The positions of the genes in the barley genome have been determined with high resolution by integrating the new PcG data with data that are publicly available. Linkage analysis was performed with the software JoinMap 4.0 [52] by adding the HvFIE and HvEZ markers to the 'OWB-D' x 'OWB-R' map [53], http:// wheat.pw.usda.gov/ggpages/maps/OWB), and the $\mathrm{HvSu}(z) 12 a$ and $\mathrm{HvSu}(z) 12 b$ markers to the 'L94' $\mathrm{x}$ 'Vada' map [49], http://wheat.pw.usda.gov/report?class=map$\underline{\text { data\&name }=\text { Barley },+L 94+x+V a d a,+2006)}$.

\section{RNA isolation and first strand CDNA synthesis}

Total RNA was isolated from roots, shoots, apical meristems, first leaves of seedlings, pistils, stamens, whole flowers before fertilization (immature flower, IMF), seeds $1-3,3-5,5-10,10-15$ days after flowering (DAF), and aerial parts after hormonal treatment, respectively, using TRI REAGENT (SIGMA) according to the instructions of the manufacturer. First strand CDNA synthesis was performed using $1.0 \mu \mathrm{g}$ total RNA, $0.5 \mu \mathrm{g}$ 3' RACE Adapter primer 5'-GGCCACGCGTCGACTAGTAC (T) $)_{17}-3^{\prime}$ (Invitrogen), $1 \mathrm{mM}$ dNTPs and $200 \mathrm{U}$ M-MuLV reverse transcriptase (Invitrogen,) in $20 \mu \mathrm{L}$ total volume, according to the specifications of the manufacturer.

\section{Expression analysis of barley PcG genes}

Qualitative RT-PCR was used for examining the expression of the $H v F I E, H v E(Z), H v S u(z) 12 a, H v S u(z) 12 b$ and $\mathrm{HvSu}(z) 12 c$ barley homologues in different tissues. cDNAs produced from $1 \mu \mathrm{g}$ of total RNA from roots, shoot meristems, young shoots, leaves, stamens, and pistils before fertilization from a medium-seed-size cultivar, Carina, were used. The primer pair Barley Actin F/Barley Actin R, amplifying a $1111 \mathrm{bp}$ fragment of the barley actin coding gene [AY145451], was used as internal control for successful cDNA synthesis. The PCR conditions for actin were: initial denaturation at $94^{\circ} \mathrm{C}$ for $3 \mathrm{~min}$, then 30 cycles at $94^{\circ} \mathrm{C}$ for $30 \mathrm{~s}, 70^{\circ} \mathrm{C}$ for $1 \mathrm{~min}, 72^{\circ} \mathrm{C}$ for $2 \mathrm{~min}$ and final extension at $72^{\circ} \mathrm{C}$ for $15 \mathrm{~min}$. The PCR conditions for the $H \nu F I E$ were: initial denaturation at $94^{\circ} \mathrm{C}$ for 2 min, then $30 \mathrm{cycles}$ of $94^{\circ} \mathrm{C}$ for $30 \mathrm{sec}, 53^{\circ} \mathrm{C}$ for $30 \mathrm{sec}$, $72^{\circ} \mathrm{C}$ for $40 \mathrm{sec}$ and final extension at $72^{\circ} \mathrm{C}$ for $10 \mathrm{~min}$. The same thermocycler program was used for the fragment amplification of the other four genes, except for the annealing step which was $57^{\circ} \mathrm{C}$ for $\mathrm{HvE}(\mathrm{Z}), \mathrm{HvSu}(z) 12 b$, and $\mathrm{HvSu}(z) 12 a$, and $62^{\circ} \mathrm{C}$ for $\mathrm{HvSu}(\mathrm{Z}) 12 \mathrm{c}$ respectively. 
Table 1: Protein sequences used for alignments and phylogenetic tree construction.

\begin{tabular}{|c|c|c|}
\hline Organism name & Gene name & Accession number \\
\hline Arabidopsis thaliana & AtFIE & AF129516 \\
\hline Catalpa speciosa & EgrFIE & $\underline{\text { AY150282 }}$ \\
\hline Eucalyptus grandis & CspFIE & $\underline{\text { AY150283 }}$ \\
\hline Hordeum vulgare & HvFIE & $\underline{\mathrm{TC} 134355}$ \\
\hline Oryza sativa nipponbare & OsnFIE2 & $\underline{B A D 03073}$ \\
\hline Oryza sativa japonicum & OsjFIE & $\underline{B A D 03075}$ \\
\hline Sorghum bicolor & SbiFIE1 & AAS82595 \\
\hline Sorghum bicolor & SbiFIE2 & $\underline{\text { AAS82596 }}$ \\
\hline Zea mays & ZmFIE1 & AY061964 \\
\hline Zea mays & ZmFIE2 & $\underline{\text { AY061965 }}$ \\
\hline Arabidopsis thaliana & AtSWN & NP 567221 \\
\hline Arabidopsis thaliana & AtCLF1 & $\underline{A A C 23781}$ \\
\hline Arabidopsis thaliana & AtMEA & $\underline{\mathrm{AAC} 39446}$ \\
\hline Hordeum vulgare & HvEZ & AK251149 \\
\hline Oryza sativa indica & OsiEZ1 & $\underline{B A D 69169}$ \\
\hline Oryza sativa japonicum & OsjEZ & $\underline{\text { CAD18871 }}$ \\
\hline Petunia hybrida & PhCLF1 & $\underline{B A C 84950}$ \\
\hline Petunia hybrida & PhCLF2 & BAC84951 \\
\hline Petunia hybrida & PhCLF3 & $\underline{B A C 84952}$ \\
\hline Triticum monococcum & TmEZ & $\underline{A B \mid 94364}$ \\
\hline
\end{tabular}


Table 1: Protein sequences used for alignments and phylogenetic tree construction. (Continued)

\begin{tabular}{|c|c|c|}
\hline Zea mays & MEZ1 & $\underline{\mathrm{AF} 443596}$ \\
\hline Zea mays & MEZ2 & AF443597 \\
\hline Zea mays & MEZ3 & $\underline{\text { AF443598 }}$ \\
\hline Arabidopsis thaliana & AtEMF2 & $\underline{B A B 58956}$ \\
\hline Arabidopsis thaliana & AtIEMF2-isoform & $\underline{\mathrm{O} 8 L 6 Y 4-2}$ \\
\hline Arabidopsis thaliana & AtFIS2, & $\underline{A B B 84250}$ \\
\hline Arabidopsis thaliana & AtFIS2b & $\underline{\text { AAD09104 }}$ \\
\hline Arabidopsis thaliana & AtVRN2 & $\underline{\text { AAL32135 }}$ \\
\hline Dendrocalamus latiflorus & DendrEMF2 & $\underline{\mathrm{ABB} 77210}$ \\
\hline Hordeum vulgare & HvSu(z)12a (HvEMF2a) & BAD99130 \\
\hline Hordeum vulgare & HvSu(z)12b (HvEMF2b & $\underline{B A D 99131}$ \\
\hline Hordeum vulgare & HvSu(z)12c (HvEMF2c) & BAD99132 \\
\hline Oryza sativa & OsEMF & $\underline{\mathrm{AAQ} 84239}$ \\
\hline Oryza sativa japonica & OsVEF & $\underline{\mathrm{AP} 005912}$ \\
\hline Oryza sativa & OsEMF-like & $\underline{\text { Q7XSNO }}$ \\
\hline Triticum aestivum & TmEMF & $\underline{\text { AY887064 }}$ \\
\hline Yucca filamentosa & YfEMF2 & $\underline{\mathrm{ABD} 85300}$ \\
\hline Zea mays & ZmEMF2-like (VEF101) & $\underline{\mathrm{AAO} 84022}$ \\
\hline Zea mays & ZmEMF-like & $\underline{A B C 69154}$ \\
\hline Drosophila melanogaster & DmSu_z_12 & $\underline{\text { AAF73149 }}$ \\
\hline Mus musculus & $\operatorname{MmSu}(\mathrm{z}) 12$ & $\underline{B A C 65495}$ \\
\hline Homo sapiens & $\mathrm{HsSu}(\mathrm{z}) 12$ & BAA09931 \\
\hline
\end{tabular}


Table 2: Primers used for expression analysis and mapping.

\begin{tabular}{|c|c|c|c|c|}
\hline Gene & Primer & Sequence (5'-3') & $\operatorname{Tm}\left({ }^{\circ} \mathrm{C}\right)$ & Fragment (bp) \\
\hline & Expression & & & \\
\hline \multirow[t]{2}{*}{$H V F I E$} & HvFIE F1 & $\begin{array}{l}\text { GTGCCCGATTGTGACA } \\
\text { TITGGTTT }\end{array}$ & 70 & 264 \\
\hline & HvFIE R1 & $\begin{array}{l}\text { CACGGCGGTTTTTGCT } \\
\text { TCCTTC }\end{array}$ & 68 & \\
\hline \multirow[t]{2}{*}{$H v E(Z)$} & $\mathrm{HvE}(\mathrm{Z}) \mathrm{F} 1$ & $\begin{array}{l}\text { AAGCATCTGGTTCTCA } \\
\text { TCGTC }\end{array}$ & 62 & 293 \\
\hline & $\mathrm{HvE}(\mathrm{Z}) \mathrm{R} 1$ & $\begin{array}{l}\text { TGGTCCACCTCAACAA } \\
\text { GTAGA }\end{array}$ & 62 & \\
\hline \multirow[t]{2}{*}{$\mathrm{HvSu}(\mathrm{z}) 12 a$} & HvSu(z)12a F1 & $\begin{array}{l}\text { TCGTGACTCGGTAGGA } \\
\text { AACATTG }\end{array}$ & 68 & 261 \\
\hline & HvSu(z)12a R1 & $\begin{array}{l}\text { CCAATGTTAATAGGTG } \\
\text { TITCAAG }\end{array}$ & 62 & \\
\hline \multirow[t]{2}{*}{$\mathrm{HvSu}(z) 12 b$} & $\mathrm{HvSu}(\mathrm{z}) 12 \mathrm{~b} F 1$ & $\begin{array}{l}\text { GTATATGAGTTGAGCA } \\
\text { TAGTGC }\end{array}$ & 62 & 278 \\
\hline & $\mathrm{HvSu}(\mathrm{z}) 12 \mathrm{~b}$ R1 & $\begin{array}{l}\text { TICAGATGGATTTCATT } \\
\text { ACAGC }\end{array}$ & 60 & \\
\hline \multirow[t]{2}{*}{$\mathrm{HvSu}(\mathrm{z}) 12 \mathrm{c}$} & $\mathrm{HvSu}(\mathrm{z}) 12 \mathrm{cF}$ & $\begin{array}{l}\text { ATGTGCCGTCAACCGT } \\
\text { CCACG }\end{array}$ & 68 & 463 \\
\hline & $\mathrm{HvSu}(\mathrm{z}) 12 \mathrm{c} \mathrm{R}$ & $\begin{array}{l}\text { CTCCAGCTTGCCCTTG } \\
\text { TGAAG }\end{array}$ & 66 & \\
\hline \multirow[t]{4}{*}{ HvActin } & Barley Actin F & $\begin{array}{l}\text { ATGGCTGACGGTGAG } \\
\text { GACATCCAGCC }\end{array}$ & 72 & 1111 \\
\hline & Barley Actin R & $\begin{array}{l}\text { TCAGAAGCACTTCCTG } \\
\text { TGGACGATCGC }\end{array}$ & 71 & \\
\hline & HvActin F & $\begin{array}{l}\text { GCCGTGCTTTCCCTCT } \\
\text { ATG }\end{array}$ & 60 & 235 \\
\hline & HvActin R & $\begin{array}{l}\text { GCTTCTCCTTGATGTCC } \\
\text { CTTA }\end{array}$ & 62 & \\
\hline \multirow[t]{3}{*}{ HVA22 } & HVA22 F & $\begin{array}{l}\text { TGGCGCTCCCGCAGTT } \\
\text { CAAG }\end{array}$ & 64 & 123 \\
\hline & HVA22R & $\begin{array}{l}\text { CCTTGAGTATGTGCAC } \\
\text { CTTGTG }\end{array}$ & 62 & \\
\hline & Mapping & & & \\
\hline \multirow[t]{2}{*}{$H v F I E$} & HvFIE F2 & $\begin{array}{l}\text { GTGGGAGCCAAAAAC } \\
\text { AAAAG }\end{array}$ & 60 & 262 \\
\hline & HvFIE R2 & $\begin{array}{l}\text { GGCGTCACAGGCTAA } \\
\text { GTAAGG }\end{array}$ & 61 & \\
\hline \multirow[t]{2}{*}{$H v E(Z)$} & $\mathrm{HvE}(\mathrm{Z}) \mathrm{F} 2$ & $\begin{array}{l}\text { AAATCAGATGTTGCAG } \\
\text { GATGG }\end{array}$ & 60 & 550 \\
\hline & $\mathrm{HvE}(\mathrm{Z}) \mathrm{R} 2$ & $\begin{array}{l}\text { GCTCCCTTGCATAGAT } \\
\text { ACCAAC }\end{array}$ & 61 & \\
\hline \multirow[t]{2}{*}{ HvSu(z) $12 a$} & $\operatorname{HvSu}(\mathrm{z}) 12 \mathrm{a} F 2$ & $\begin{array}{l}\text { ACTCGTGCAGAACCCA } \\
\text { AGAC }\end{array}$ & 60 & 576 \\
\hline & $\operatorname{HvSu}(\mathrm{z}) 12 \mathrm{a}$ R2 & $\begin{array}{l}\text { ACCCATCCCAGCTACA } \\
\text { ACAG }\end{array}$ & 60 & \\
\hline \multirow[t]{2}{*}{$\mathrm{HvSu}(\mathrm{z}) 12 b$} & $\operatorname{HvSu}(z) 12 b$ F2 & $\begin{array}{l}\text { ATATTCCTTGGGCCTG } \\
\text { TGAG }\end{array}$ & 59 & 308 \\
\hline & $\mathrm{HvSu}(\mathrm{z}) 12 \mathrm{~b}$ R2 & $\begin{array}{l}\text { TGGAACAGAACACGA } \\
\text { CGAAG }\end{array}$ & 54 & \\
\hline
\end{tabular}


Quantitative real-time RT-PCR was performed with cDNA synthesized from $1 \mu \mathrm{g}$ of total RNA from immature flowers, seeds 1-3 DAF, 3-5 DAF, 5-10 DAF, and 1015 DAF from Caresse and Ippolytos, respectively, and aerial parts of Caresse seedlings after ABA treatment. For each sample a reaction was set up in a PCR reaction mix $(20 \mu \mathrm{l})$ containing $5 \mu \mathrm{l}$ of the 1:200 diluted cDNA, 0.25 $\mu \mathrm{M}$ of each primer and $1 \times$ Platinum SYBR Green qPCR Supermix-UDG (Invitrogen, Paisley, UK) and using an Opticon 2 (M) Research, Waltham, MA) real-time PCR system and the Opticon Monitor 3 software package (M) Research). Each reaction was performed in triplicates. General thermocycler conditions were $50^{\circ} \mathrm{C}$ for $2 \mathrm{~min}$, $95^{\circ} \mathrm{C}$ for $2 \mathrm{~min}$, then 42 cycles of $95^{\circ} \mathrm{C}$ for $30 \mathrm{sec}$, annealing $\left[H v E(Z): 56^{\circ} \mathrm{C} ; H v F I E: 57^{\circ} \mathrm{C} ; \mathrm{HvSu}(z) 12 b: 54^{\circ} \mathrm{C}\right.$, respectively] for $30 \mathrm{sec}, 72^{\circ} \mathrm{C}$ for $30 \mathrm{sec}$, then $72^{\circ} \mathrm{C}$ for 5 min and plate read at $82^{\circ} \mathrm{C}$. To identify the PCR products a melting curve was performed from $65^{\circ} \mathrm{C}$ to $95^{\circ} \mathrm{C}$ with observations every $0.2^{\circ} \mathrm{C}$ and a 10-s hold between observations. Relative quantification and statistical analysis were performed with the REST software [54] and using actin as the reference gene with HvActinF/HvActinR as primers. The barley gene $H V A 22$, which is known to be induced by ABA [55] was used as a positive control. All primers used in expression analysis correspond to nonconserved regions and are shown in Table 2.

\section{Results \\ Identification of barley PcG gene homologues and analysis of putative proteins}

A blast search of the Hordeum vulgare EST database in TIGR http://www.tigr.org detected an EST (TC134355) corresponding to FIE and an EST (TC140937) corresponding to $E(Z)$, respectively. TC134355 contains a full length cDNA sequence (1623 nt translating to 378 aa) of a barley FIE homologue, which we termed HVFIE. Amino acid sequence alignment of plant FIE homologues revealed that the HvFIE putative protein belongs to the highly conserved FIE family and that it contains the seven characteristic WD40 repeats (Figure 1).

TC140937 contains a partial cDNA sequence (1151 nt) corresponding to a barley $E(Z)$ homologue which we termed $H v E(Z)$. A tblastn search with this sequence revealed a full length mRNA sequence (AK251149) from the BARLEY DB http://www.shigen.nig.ac.jp/barley/ which contains 3092 nt encoding 884 aa of an $E(Z)$ homologue. The putative $E(Z)$ protein from barley, HvEZ, contains the characteristic SET-domain and the cysteine-rich region as shown in the alignment of the $\mathrm{E}(\mathrm{Z})$ amino acid sequences from different organisms (Figure 2). The barley protein has $94 \%$ identity with the $E(Z)$ protein from wheat (TmEZ), and 70\% identity with the EZ2 and EZ3 proteins from maize (MEZ2, MEZ3).
A search in GenBank identified three complete mRNA sequences from barley coding for $\mathrm{Su}(\mathrm{z}) 12$-like homologues with accession numbers AB085817, AB085818, and $\mathrm{AB} 085819$ which we named $\mathrm{HvSu}(z) 12 a, \mathrm{HvSu}(z) 12 b$, and $\mathrm{HvSu}(z) 12 c$, respectively. These sequences encode putative proteins of 660 aa, 637 aa, and 460 aa, respectively. They all contain the characteristic zinc finger domain found in VEFS proteins, and the $\mathrm{HvSu}(\mathrm{z}) 12 \mathrm{a}$, $\mathrm{HvSu}(\mathrm{z}) 12 \mathrm{~b}$ putative proteins also contain the conserved VEFS domain as shown in the VEFS protein alignment (Figure 3). The HvSu(z)12c amino acid sequence terminates before the VEFS domain but this could be due, in part, to a sequencing problem at the 3 ' end of the particular cDNA as the nucleotide sequence of $\underline{\mathrm{AB} 085819}$ contains unexplained repeats. Because of this problem we decided not to study $\mathrm{HvSu}(\mathrm{z}) 12 \mathrm{c}$ any further. $\mathrm{HvSu}(\mathrm{z}) 12 \mathrm{a}$ and $\mathrm{HvSu}(\mathrm{z}) 12 \mathrm{~b}$ share $58 \%$ identity with each other. $\mathrm{HvSu}(\mathrm{z}) 12 \mathrm{~b}$ is highly similar to a wheat EMF protein TaEMF, with $93 \%$ identity.

A phylogenetic analysis of FIE homologues in plants showed that HvFIE is more closely related to other cereal FIE proteins, specifically, ZmFIE2 from maize and OsnFIE2 from rice (Figure 4A). Similarly, phylogenetic analysis of $E(Z)$ proteins from monocots and dicots showed that HvEZ groups out together with TmEZ, MEZ2, MEZ3 and OsiEZ1, whereas AtCLF, MEZ1, OsjEZ form another cluster and AtSWN and AtMEA are more distant to both groups (Figure 4B). A phylogenetic analysis of various VEFS proteins from different organisms (Figure $4 \mathrm{C}$ ) showed that $\mathrm{HvSu}(\mathrm{z}) 12 \mathrm{~b}$ is more closely related to EMF proteins from wheat, dendrocalamus, oryza and maize, whereas $\mathrm{HvSu}(\mathrm{z}) 12 \mathrm{a}$ forms a cluster with two other EMF proteins from rice. They are both more distantly related to the Arabidsopsis EMF, FIS2, and VRN proteins and their isoforms, and from the animal $\mathrm{Su}(\mathrm{z}) 12$ homologues (Drosophila, mouse, and human) which cluster together.

\section{Mapping of barley PcG genes}

HindIII cleaved amplified polymorphic sequence (CAPS) and DdeI derived cleaved amplified polymorphic sequence (dCAPS) markers were developed for the mapping of $H v E(Z)$ and $H v F I E$ on the OWB molecular linkage map, respectively. Linkage analysis revealed that $H v E(Z)$ maps in a cluster of 43 molecular markers in the centromeric region of chromosome $4 \mathrm{H}$, and HvFIE co-segregates with RFLP marker MWG808 and other 52 markers in the pericentric region of chromosome $7 \mathrm{H}$ (Figure 5). CAPS (DdeI) and dCAPS (RsaI) marker segregation analyses were performed for mapping $\operatorname{HvSu}(z) 12 a$ and $\mathrm{HvSu}(z) 12 b$ on the LxV linkage map. $\mathrm{HvSu}(z) 12 a$ and $\mathrm{HvSu}(z) 12 b$ are located on the short arm of chromosome $2 \mathrm{H}$ and on the subcentromeric region of the long arm of chromosome $5 \mathrm{H}$, respectively (Figure 5). 


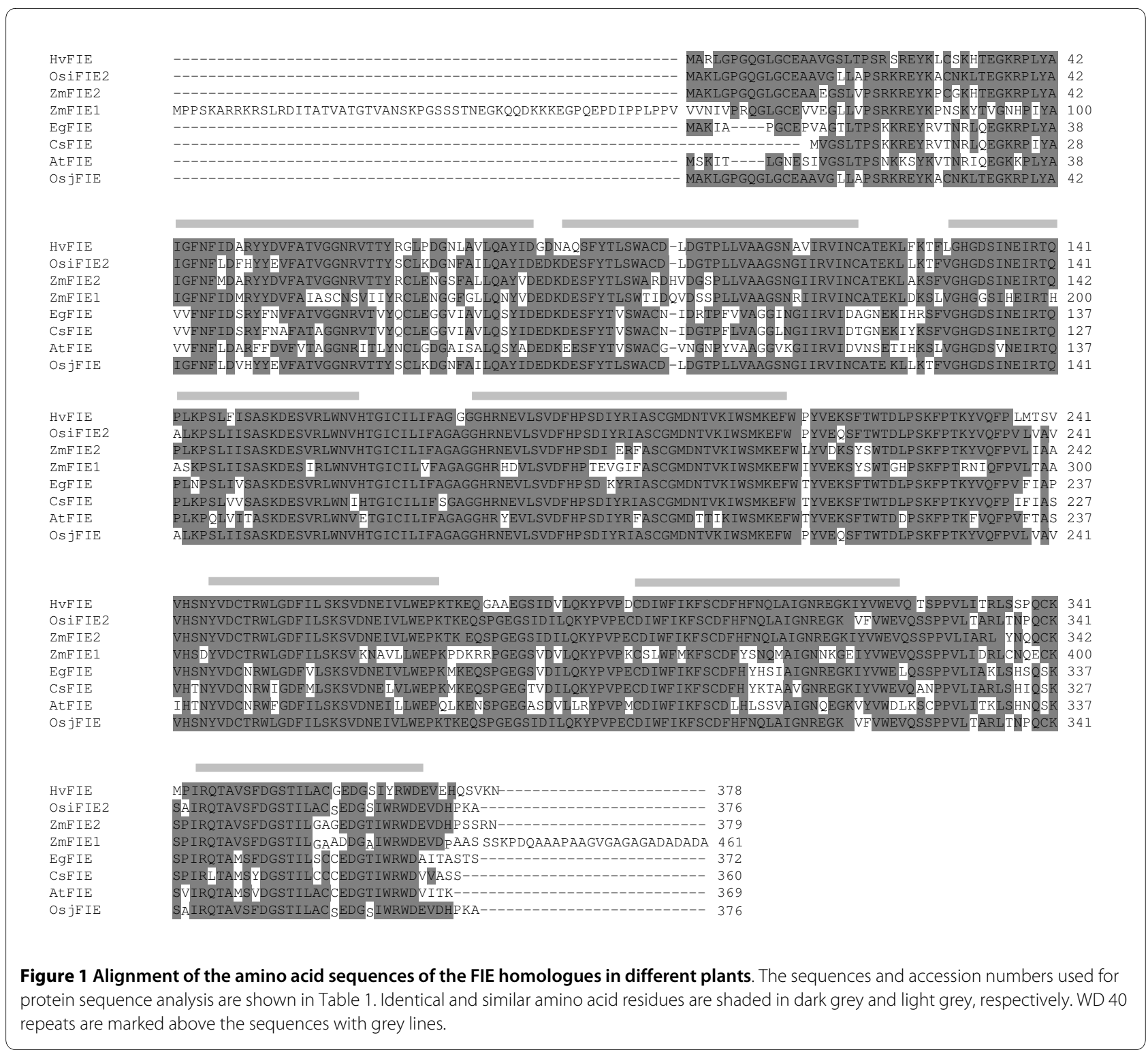

Differential expression of barley PcG genes in different tissues and seed developmental stages and in two cultivars with varying seed size

Qualitative RT-PCR was performed in order to examine the expression of $H \nu F I E, H \nu E(Z), H \nu S u(z) 12 a$ and $\mathrm{HvSu}(z) 12 b$ in different tissues, in a medium-seed-size cultivar, Carina (Figure 6A). The HvFIE mRNA is abundant in shoot meristems, young shoots, pistils before fertilization and seeds of 1-2 DAF and 3-5 DAF, whereas it is hardly detectable in roots, leaves and stamens. The $H v E(Z)$ transcript is abundant in young shoots and 3-5 DAF seeds, moderate in the other tissues, and detectable in stamens. The $\mathrm{HvSu}(z) 12 b$ transcript is abundant in young shoots, at moderate levels in 1-2 DAF seeds and at low levels in the other tissues. The $\mathrm{HvSu}(z) 12 c$ transcript is abundant in young shoots, present at moderate levels in leaves, at low levels in seeds 1-2 DAF and 3-5 DAF and undetectable in the other tissues examined, whereas the $\mathrm{HvSu}(z) 12 a$ transcript is undetectable in all tissues examined except from young shoots where a very faint band is observed.

Quantitative real-time PCR was performed in order to compare the levels of $H v F I E, H v E(Z)$, and $H v S u(z) 12 b$ mRNA accumulation at different stages of seed development and between two barley cultivars with different seed size, Caresse (larger seed size) and Ippolytos (smaller seed size) (Figure 6B). $H v S u(z) 12 a$ was not included in this analysis, owing to its negligible expression. Similarly, $\mathrm{HvSu}(z) 12 c$ was excluded due to undetectable or low expression in reproductive tissue and seed, respectively. 


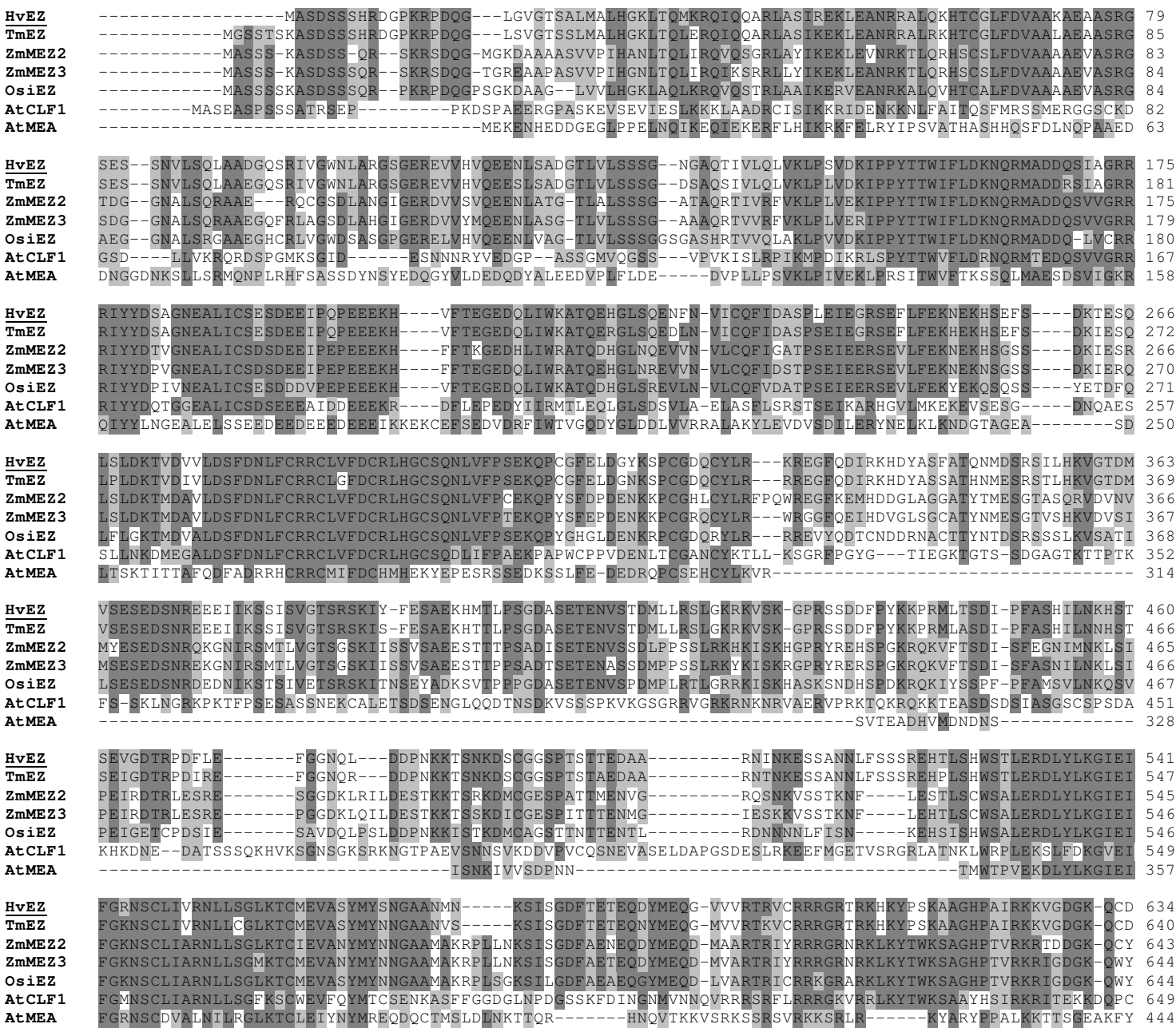

\section{Cys-rich domain}

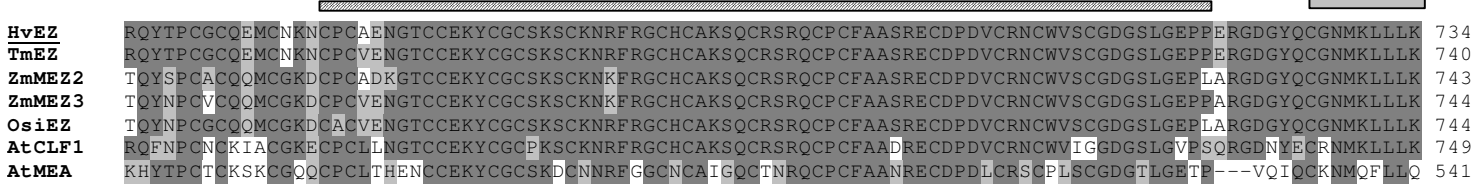

\section{SET domain}

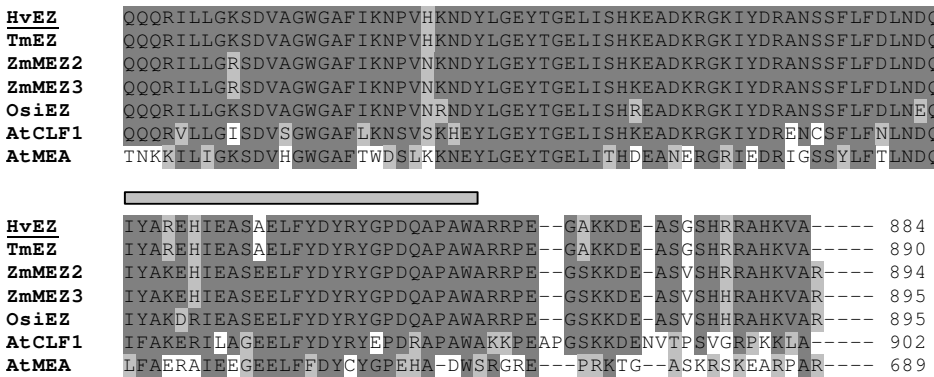

Figure 2 Alignment of the amino acid sequences of the $E(Z)$ homologues from different plants. Sequences and accession numbers are shown in Table 1. Identical and similar amino acid residues are shaded in dark grey and light grey, respectively. The cysteine rich domain and the SET-domain are shown above the sequences with hatched and gray lines, respectively. 


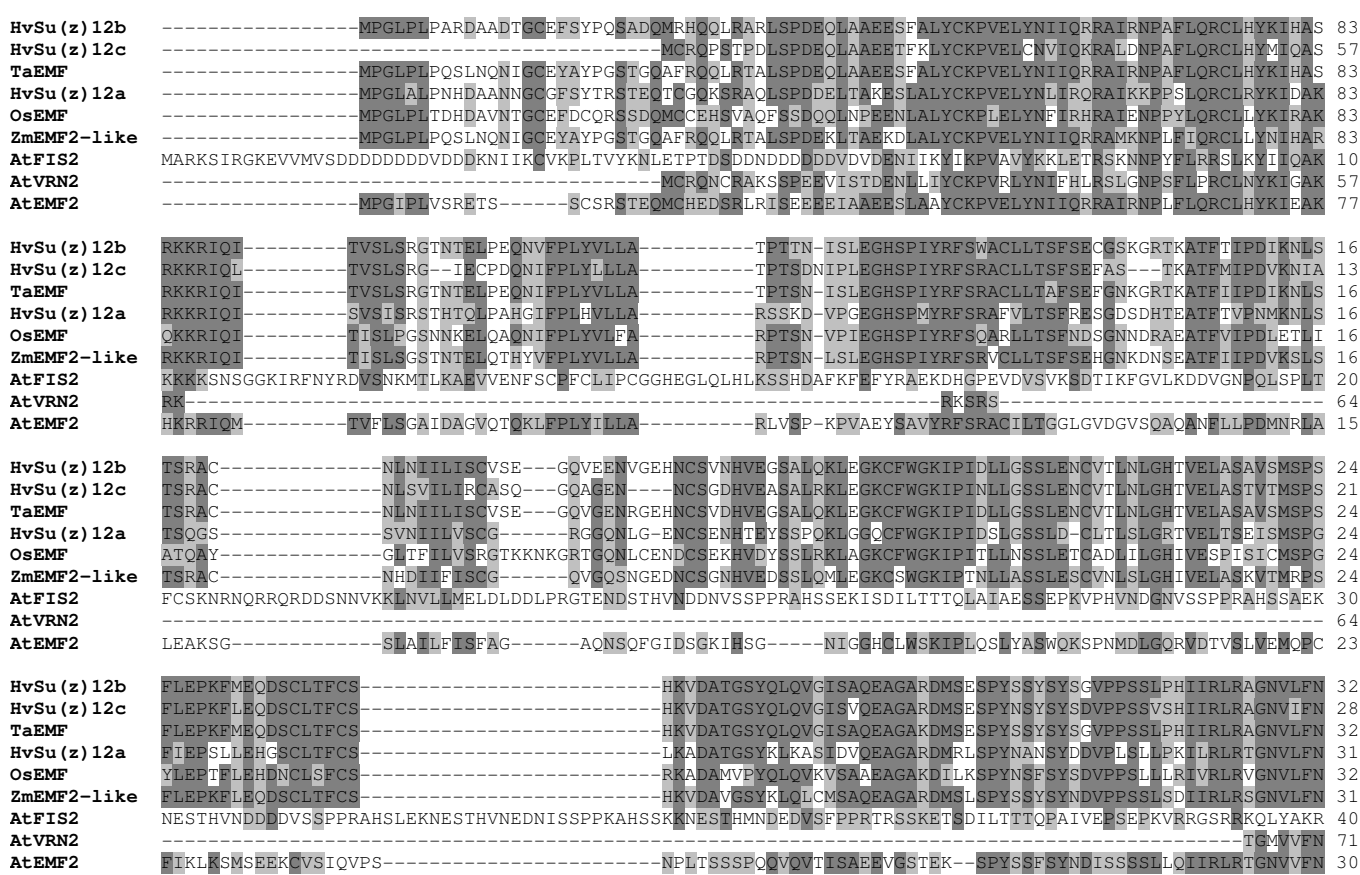

\section{ZINC FINGER}

HvSu (z) $12 b$ $\operatorname{HvSu}(z) 12 \mathrm{c}$ TaEMF

HvSu (z) $12 \mathrm{a}$

OSEMF

ZmEMF2-like

AtFIS2

AtVRN2

$\mathrm{HvSu}(\mathrm{z}) 12 \mathrm{~b}$

HvSu (z) $12 c$

TaEMF

HvSu (z) 12a

OSEMF

ZMEMF2-1ike

AtFIS2

AtVRN2
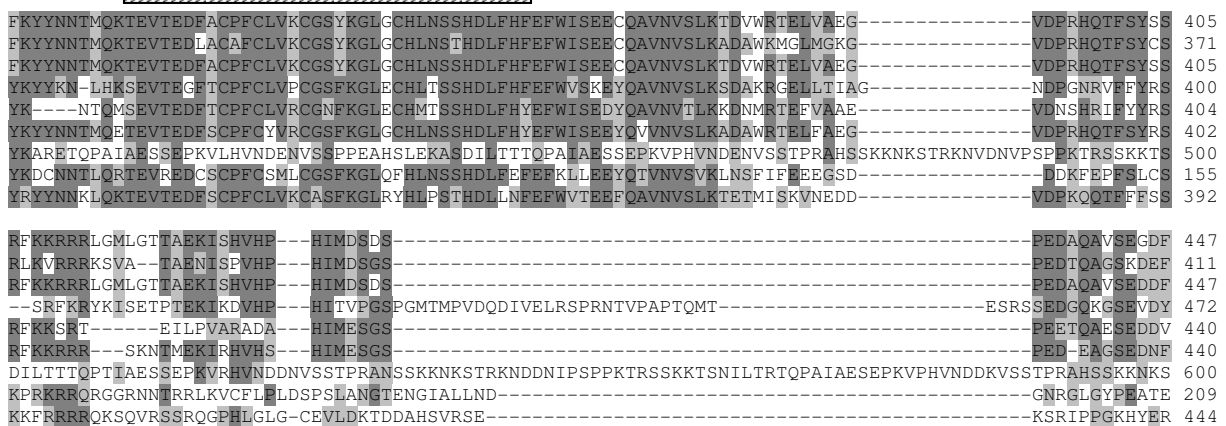

AtEMF 2

VEFS-BOX

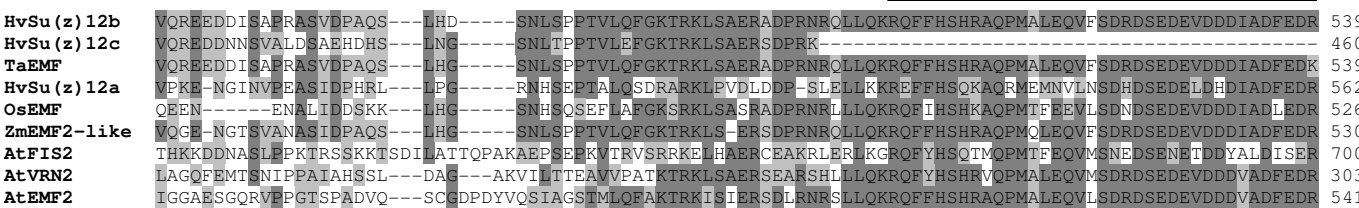

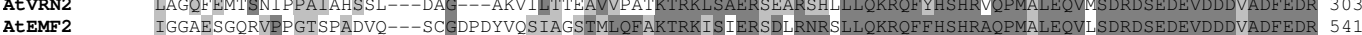

$\mathrm{HvSu}(\mathrm{z}) 12 \mathrm{~b}$

$\mathrm{HvSu}(\mathrm{z}) 12 \mathrm{c}$

TAEMF

$\operatorname{HvSu}(z) 12 a$

OSEMF

ZMEMF2-1ike

AtFIS2

AtVRN2

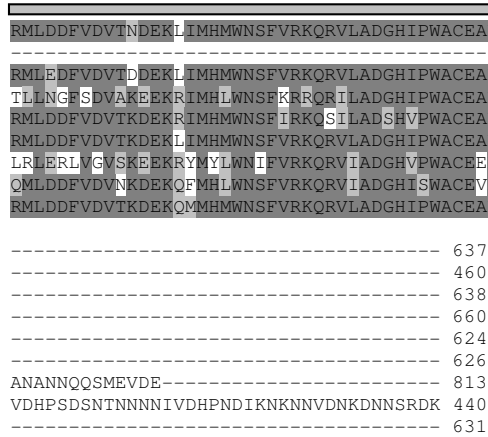

Figure 3 Alignment of the amino acid sequences of Su(z) 12 protein homologues from different plants. Sequences and accession numbers are shown in Table 1. Identical and similar amino acid residues are shaded in dark grey and light grey, respectively. The Zinc-finger domain and the VEFS box are indicated by hatched and gray lines, respectively. 
A)

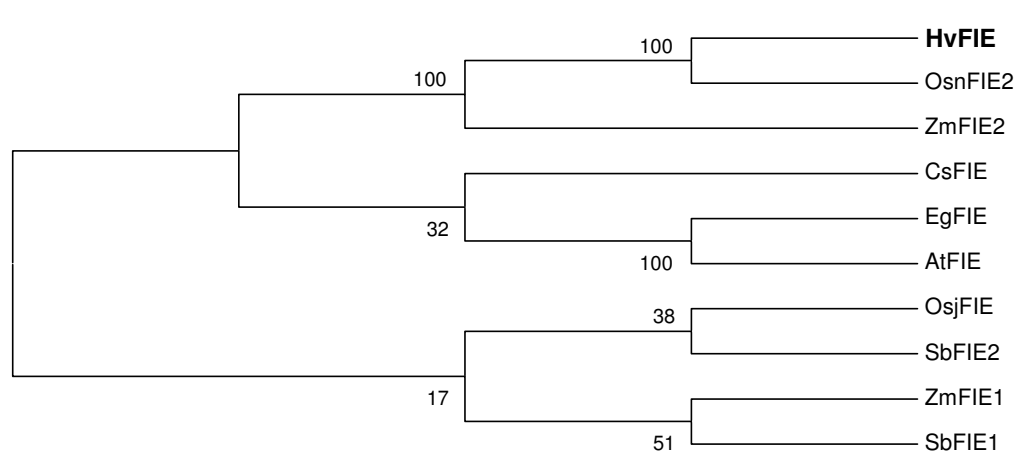

B)
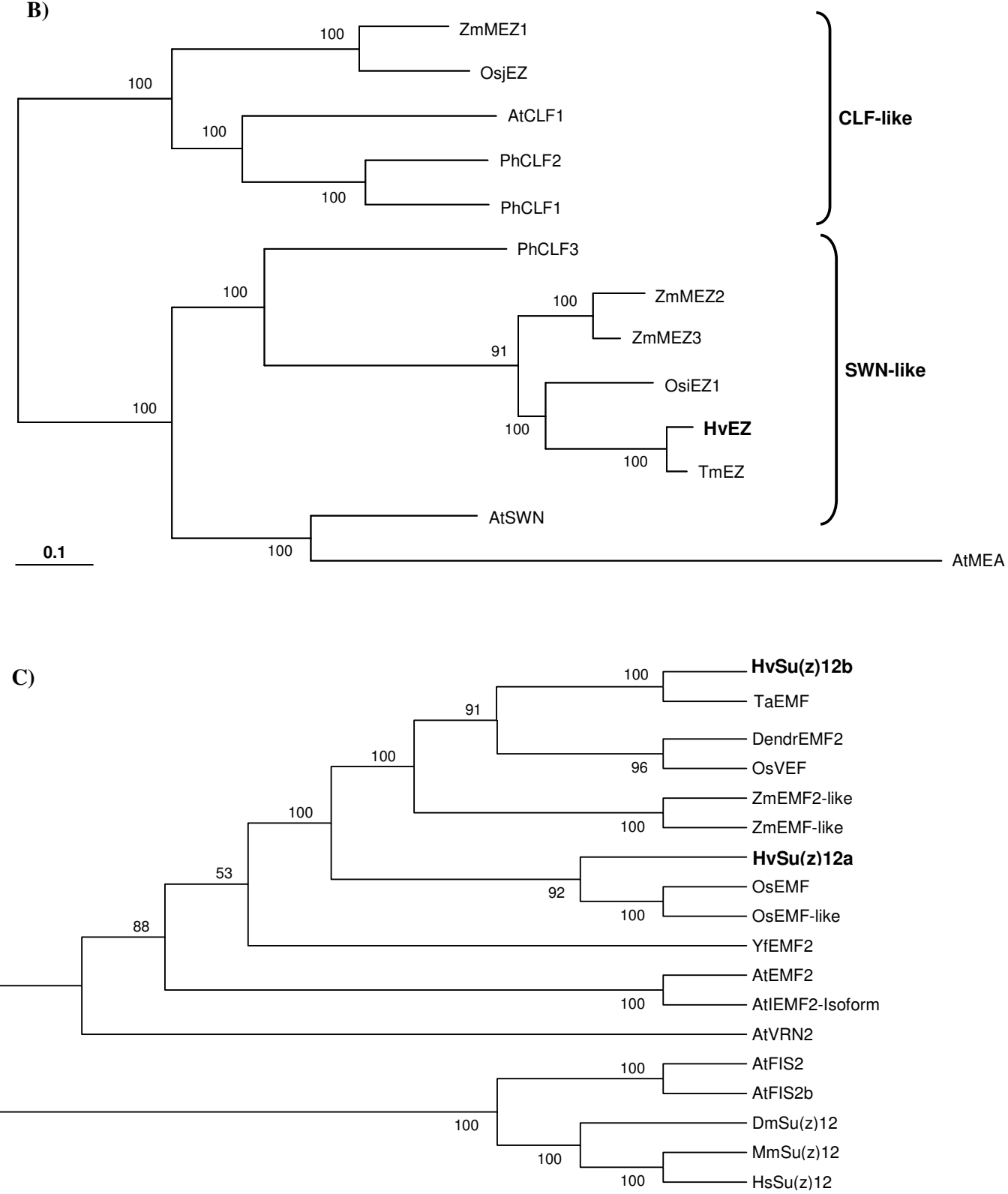

Figure 4 Phylogenetic analysis of PcG proteins. Phylogenetic trees of PcG homologues from different organisms. A) FIE. B) E(Z). C) Su(z) 12. Barley sequences are in bold. Sequences and accession numbers are shown in Table 1. 
Location of $H v E(Z)$ and $H v F I E$ on the barley OWB map
Location of $\mathrm{HvSu}(\mathrm{z}) 12 \mathrm{a}$ and $\mathrm{HvSu}(z) 12 b$ on the barley LxV map
4H-OWB

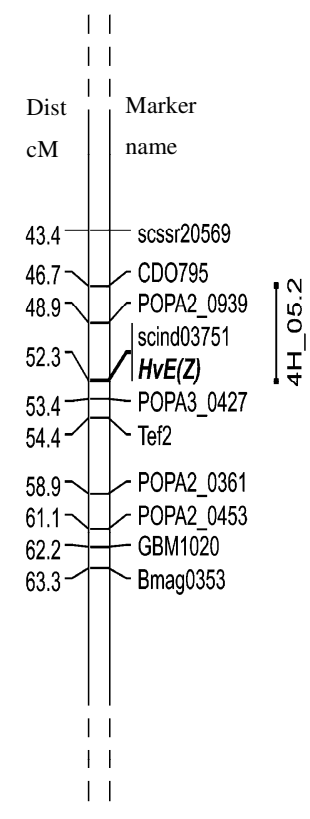

7H-OWB

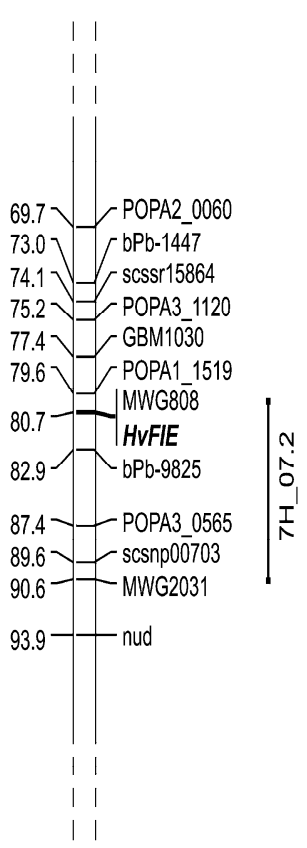

$2 H-L x V$

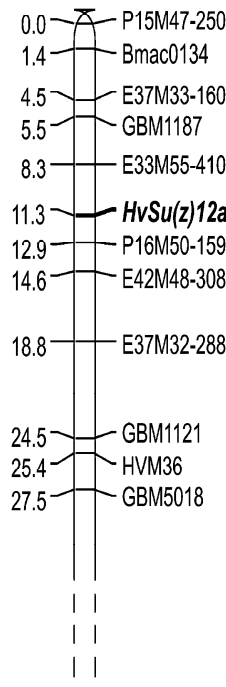

$5 H \cdot L x V$

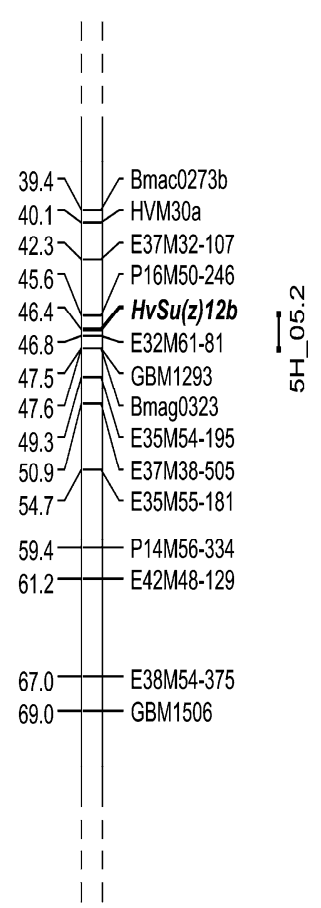

Figure 5 Mapping of barley PcG genes. Chromosomal position of barley HvE(z) and HvFIE genes on the OWB molecular linkage map and HvSu(z) $12 a$ and $\mathrm{HVSu}(z 12) b$ on the LxV molecular linkage map. Only non co-segregating markers are reported, with distances in Kosambi cM. The BIN where each PCG gene has been mapped is indicated following the notation of [49] that integrates data from 6 segregating populations including both the OWB and the LxV maps.

$H \nu F I E$ mRNA accumulation exhibits an increase after fertilization, in both Caresse and Ippolytos. In Caresse HvFIE transcript levels reach a maximum at 3-5 DAF (C7) with approximately a 5 fold increase as compared to immature flowers (C5) and decrease thereafter to about $50 \%$ in 10-15 (C9) DAF. Conversely, in Ippolytos, HvFIE exhibits a continuous induction with a pronounced increase up to 7 fold at 10-15 DAF (IP9) as compared to immature flowers (IP5). At 5-10 DAF and at 10-15 DAF, $H v F I E$ transcript levels are markedly higher in Ippolytos (approximately 1.5 and 3.5 fold, respectively) as compared to Caresse (Figure 6B).

$H v E(Z)$ transcript levels decline after 1-3 DAF (C6) in Caresse, with maximum decrease in 3-5 DAF (2 fold reduction as compared to immature flowers) whereas comparable decrease was not observed in 3-5 DAF (IP7) for Ippolytos. Contrary to Caresse, $H v E(Z)$ expression levels in Ippolytos do not show any significant changes in any of the stages before fertilization and throughout seed development.

$\mathrm{HvSu}(z) 12 b$ transcript levels are increased after fertilization at the stages 5-10 and 10-15 DAF as compared to immature flowers, both for Caresse and Ippolytos. No significant differences are observed among immature flowers, 1-3 DAF and 3-5 DAF, in either cultivar, and $\mathrm{HvSu}(z) 12 b$ levels are comparable between cultivars throughout seed development.

\section{Expression analysis of barley PcG genes after treatment with ABA}

Quantitative real time PCR was performed using total RNA from seven-day-old seedlings subjected to exogenous ABA $(100 \mu \mathrm{M})$ to examine whether $H v F I E$ and $H v E(Z)$ respond to this seed developmental and stressrelated hormone (Figure 7). HvFIE showed a striking 10 fold induction at $24 \mathrm{~h}$ after ABA spraying of seven-day- 
A)

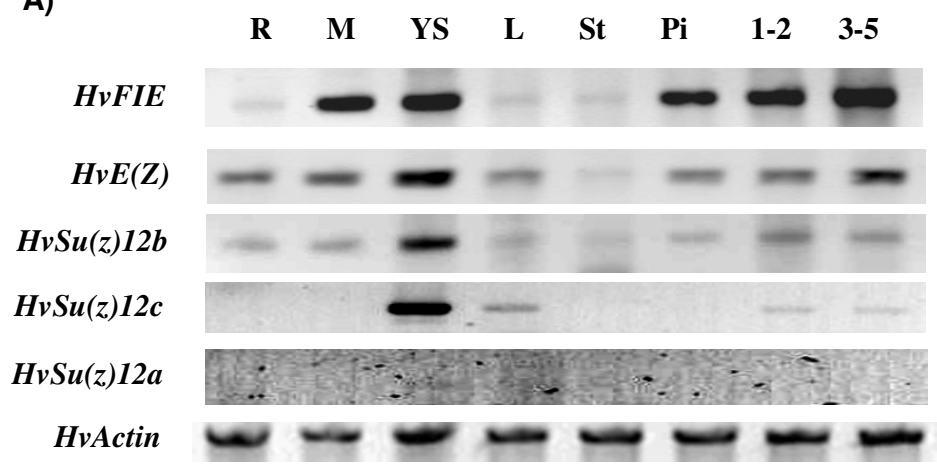

B)

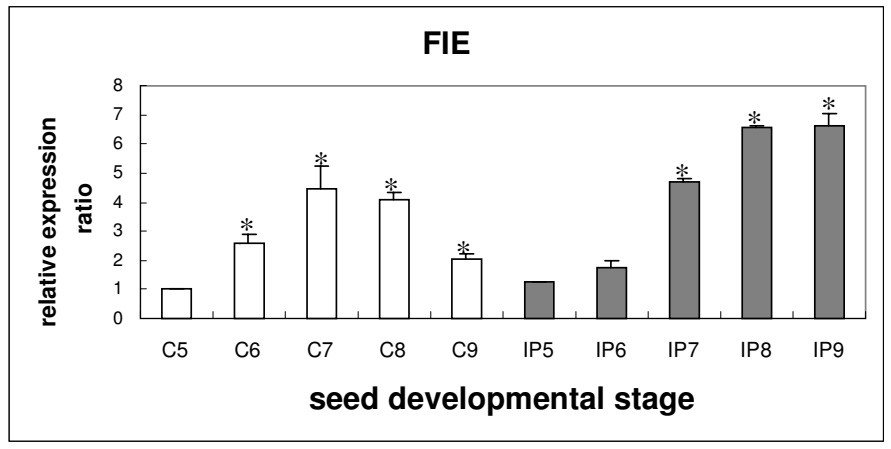

HvFIE

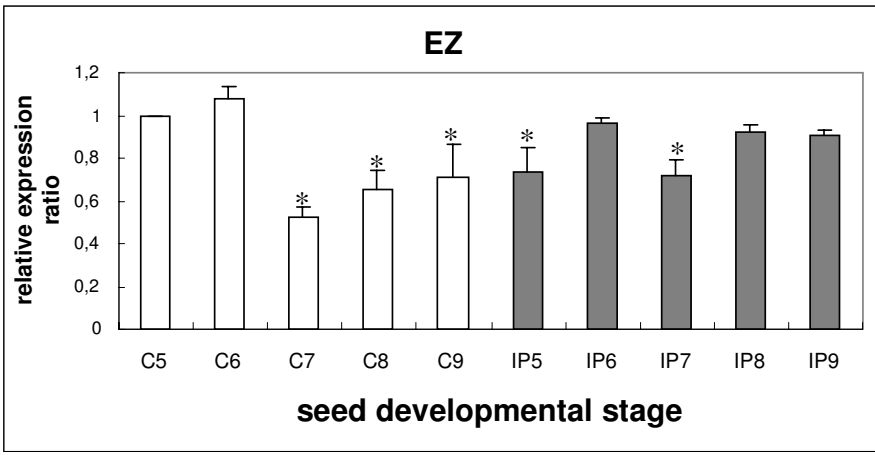

$\mathrm{HvE}(\mathrm{Z})$

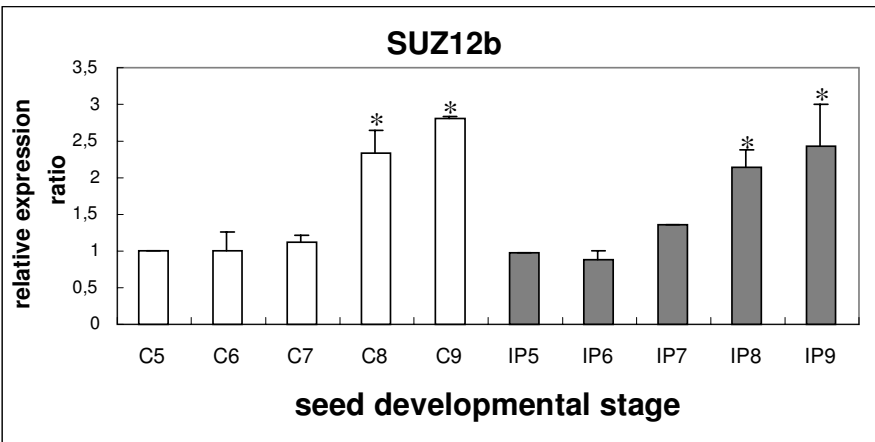

$\mathrm{HvSu}(z) 12 b$

Figure 6 A) Qualitative RT-PCR expression analysis of barley PcG genes. R, roots; M, meristem; L, Leaves; YS, young shoots; St, stamens; Pi, unfertilized pistils; 1-2, 1-2 DAF; 3-5, 3-5 DAF; HvActin, was used as the internal control. Cultivar was Carina (a medium-grain cultivar). DAF, Days after fertilization. B) Quantitative real-time RT-PCR analysis of $P \mathbf{C G}>$ genes. Expression values were normalized to those of HvActin. The relative expression ratio of each sample is compared to the control group which was C5 (Caresse immature flowers). C, cultivar Caresse, (white bars); IP, cultivar Ippolytos (grey bars). 5, Immature flower; 6, Seed 1-3 DAF; 7, Seed 3-5 DAF; 8, Seed 5-10 DAF; 9, Seed 10-15 DAF. Data represent mean values from two independent experiments with standard deviations. Values significantly different $(P<0.05)$ from the control group $(C 5)$ are marked with an asterisk. 
old seedlings, as compared to the untreated plants. $H \nu E(Z)$ showed a marked induction of approximately 4 fold, both at $6 \mathrm{~h}$ and $24 \mathrm{~h}$ after ABA treatment, as compared to the untreated control. Expression of $\mathrm{HvSu}(z) 12 b$ did not show any significant changes after ABA treatment (data not shown).

\section{Discussion}

In the current study we present the identification, mapping and expression profiles of the genes encoding PcG chromatin modifiers from barley. This work serves as a first step in understanding the role played by $P c G$ genes in the epigenetic mechanisms that control seed formation and stress response in a monocot cereal plant. Unlike dicots, where the endosperm is consumed by the embryo during seed maturation, in monocots such as cereals, the endosperm persists after embryo development is completed and constitutes the major portion of the mature kernel $[6,7]$. The endosperm of cereal crops like barley, wheat, rice, maize, stores reserves such as proteins, starch, and fatty acids, and represents $60 \%$ of the world's food and feed supply. Consequently, understanding and manipulating the molecular mechanisms governing endosperm development for increasing seed yield is of utmost interest for agriculture.

Four barley $P c G$ gene homologues encoding the putative PcG proteins HvFIE, HvEZ, $\operatorname{HvSu}(\mathrm{z}) 12 \mathrm{a}$ and $\mathrm{HvSu}(\mathrm{z}) 12 \mathrm{~b}$ were identified and analyzed. In Arabidopsis the respective PcG counterparts are [AtFIE], [AtMEA or AtSWN or AtCLF] and [AtFIS2 or AtEMF2 or AtVRN2]. Three different PcG complex variants can be formed depending on the different combinations of these subunits. The changeable subunits are the MEA and FIS2 homologues whereas FIE is likely to be common in all three complexes. The FIE, MEA, FIS2 proteins form a complex essential for viable seed formation. MEA, CLF, and SWN, constitute the three Arabidopsis E(Z) homologues, which cluster into three separate clades, and are members of different PcG complexes with distinct functions. MEA is important for proper seed development and SWN acts redundantly with MEA having a role in preventing endosperm development as well [56]. However according to another report by Spillane et al. 2007 [57], swn/clf double mutants in Arabidopsis produce normal seeds suggesting that neither SWN nor CLF has a role in seed formation. In addition, SWN and CLF are involved in the vernalization process [23]. It was proposed that these homologues have arisen through an old duplication and separation of $C L F$ from the $M E A / S W N$ lineage, which occurred before the divergence of monocots and dicots, whereas a more recent duplication produced the separation between $M E A$ and $S W N$ in only a few species [57]. No direct orthologues of MEA have been found in any other species than Arabidopsis. E(Z) homologues identified in maize and rice [58-60], two monocots with sequenced genomes, cluster in two clades: ZmMEZ2, ZmMEZ3 and OsiEZ1 form the so-called SWN-like clade, and ZmMEZ1 and OsjEZ (also named OsCLF) form the CLF-like clade. Phylogenetic analysis showed that the barley homologue HvEZ is a close relative of the wheat, rice and maize $\mathrm{E}(\mathrm{Z})$ homologues belonging in the SWN-like clade. Unlike Arabidopsis, which has at least three $E(Z)$ homologues functioning at different stages of the plant's life cycle, a second HvEZ homologue has not been identified in barley as yet. It might be possible that HvEZ is a common member of the different PcG complex variants that may be operating at different stages of barley development. However, this hypothesis awaits sequencing of the barley genome and further experimentation. In the absence of a MEA counterpart it is possible that the role of MEA is played by one of the putative SWN or CLF homologues both in barley and in the other species lacking MEA.

HvFIE maps on chromosome 7Hcen which is colinear with rice chromosome 8, where the rice OsnFIE2 homologue (Os08g04270) has been also localized. $H v E(Z)$ maps on chromosome 4Hcen which is colinear with rice chromosome 3, where the rice OsiEZ1 homologue (Os03g19480) is found [60]. Similarly, $\mathrm{HvSu}(z) 12 a$ maps on chromosome 2 Hshort which is colinear with rice chromosome 4, where the OsEMF (Os04g08034) homologue is localized, and $\mathrm{HvSu}(\mathrm{z}) 12 \mathrm{~b}$ maps on chromosome 5 Hlong which is colinear with rice chromosome 9 where the rice homologue OsVEF (Os09g13630)is localized [60]. These observations are in agreement with the extensive synteny between barley and rice chromosomes.

$H \nu F I E$ and $H \nu(E) Z$ are located in the centromeric region of chromosome $7 \mathrm{H}$ and $4 \mathrm{H}$ repectively, where important clusters of malting quality QTLs have been identified by several authors and reviewed by [61]. Noteworthy, using the Oregon Wolfe Barley map [53] that integrates 2383 loci and a comprehensive summary of 154 QTLs of malting quality http://wheat.pw.usda.gov/ ggpages $/ \mathrm{maps} / \mathrm{OWB} /$, it is possibile to relate the high resolution genomic location of the two PcG genes with historical QTL data. $H v(E) Z$ location is coincident with scind03751 and $1.1 \mathrm{cM}$ proximal to Tef2, the significant marker for the beta-Glucanase activity QTL (QBgsg.StMo-4H) identified in the Steptoe $x$ Morex population. HvFIE maps to a cluster of OPA and DArT markers that includes MWG808 and is $10 \mathrm{cM}$ proximal to MWG2031, the significant marker for both Grain protein content (QGpc.HaMo-7H) and Kernel plumpness (QKp.HaMo-7H) in the Harrington $x$ Morex population.

Likewise the map position of the two $\mathrm{Su}(\mathrm{z}) 12$ homologues $(\mathrm{HvSu}(\mathrm{z}) 12 a$ on the short arm of chromosome $2 \mathrm{H}$ and $\mathrm{HvSu}(z) 12 b$ close to the centromere of chromosome $5 \mathrm{H})$, is in proximity to genomic regions historically 

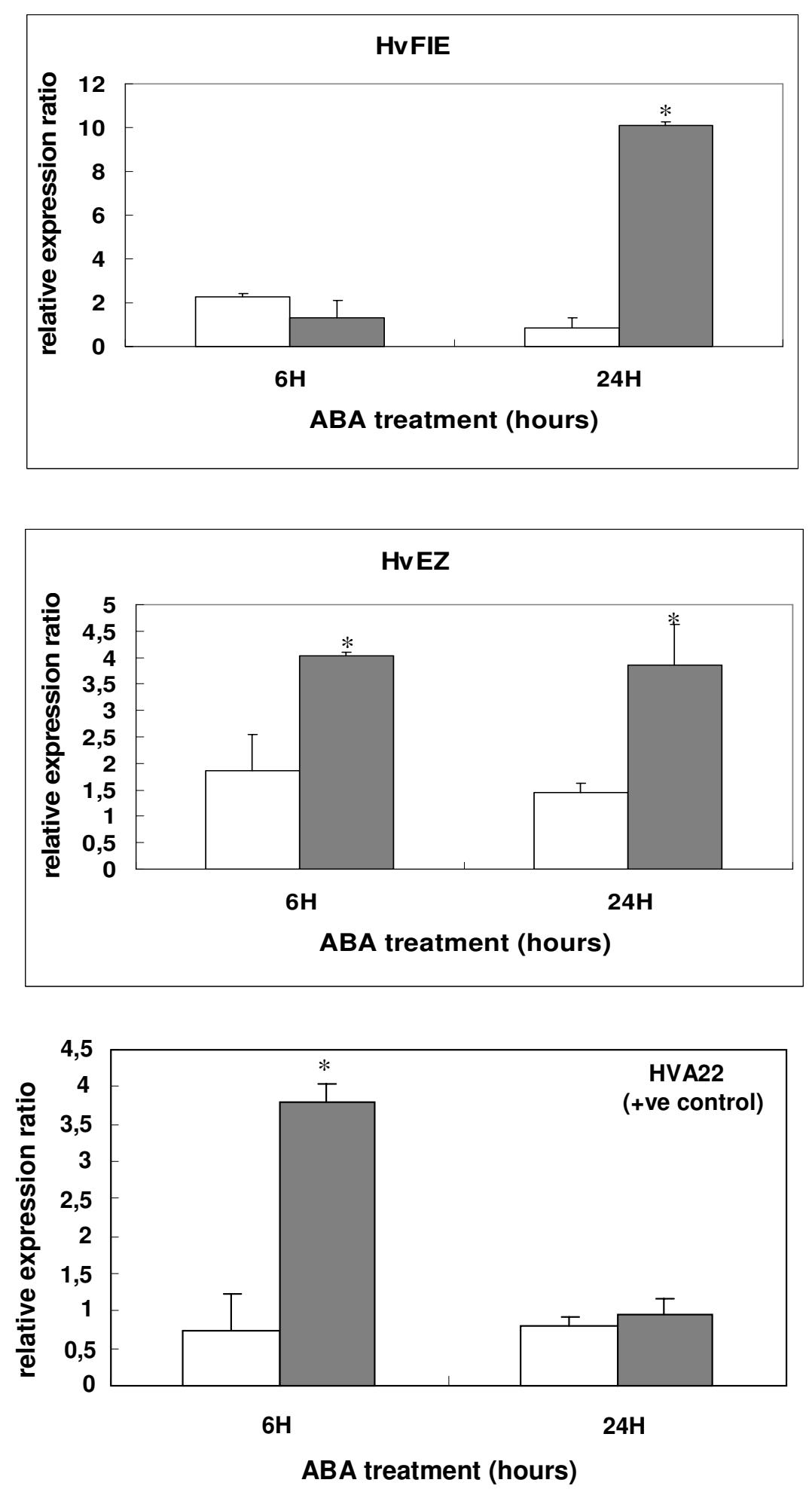

Figure 7 Expression analysis of barley PcG genes after treatment of seedlings with ABA. Quantitative real-time PCR analysis of HvFIE and HVE(Z) genes at 6 and $24 \mathrm{~h}$ after treatment of Caresse seedlings with $100 \mu \mathrm{M}$ ABA. Expression values were normalized to those of HvActin. Data represent mean values from two independent experiments with standard deviations. Relative expression ratio of each sample was compared to the control group which was untreated plants, 0 h, and was assigned the value of 1. Grey bars, hormone-treated plants for $6 \mathrm{~h}$ and $24 \mathrm{~h}$; white bars, no hormone treated plants (mocked with $\mathrm{H}_{2} \mathrm{O} /$ Tween for $6 \mathrm{~h}$ and $24 \mathrm{~h}$, respectively). Values significantly different $(\mathrm{P}<0.05)$ from the control group are marked with an asterisk. The barley gene HVA22 (known to be induced by ABA) was used as positive control. 
involved in the genetic control of malting quality traits [61]. However, all these gene-QTL relationships cannot be unequivocally established and thus further research is needed to determine the role of PcG in endospermrelated traits.

Qualitative RT-PCR analysis demonstrated that the barley $H \nu F I E$ shows a tissue expression profile similar to that of AtFIE, maize ZmFIE2 and rice OsFIE2 $[13,62,58,63,60]$ in that it is expressed in both vegetative and reproductive tissues. Similarly, the barley $H v E(Z)$ is expressed throughout development like the maize homologues ZmMEZ1, ZmMEZ2 and ZmMEZ3 [58] and the rice $E(Z)$ homologues, OsiEZ1 and OsCLF (same as OsjEZ) [60], whereas AtMEA is not expressed in leaves $[19,12,64]$. The expression pattern of $\operatorname{H\nu Su}(z) 12 b$ is similar to the rice OsEMF homologues, being expressed both in vegetative and reproductive tissues [60]. Conversely, AtFIS2 is expressed only in the central cell and endosperm [13]. No expression studies on the maize $\mathrm{Su}(z) 12$ homologues, ZmEMF-like and ZmEMF2-like, have been reported so far. The differential expression of AtMEA and AtFIS2 compared to E(Z) and $\mathrm{Su}(z) 12$ homologues from monocots and other dicots, together with the fact that the protein sequences of AtMEA and AtFIS2, are distantly related to the $\mathrm{E}(\mathrm{Z})$ and $\mathrm{Su}(\mathrm{z}) 12$ homologues from cereals and other dicots supports the view proposed by Luo et al. 2009 [60], that the MEA and FIS2 genes arose only within the Brassicaceae.

In Arabidopsis, mutations in the $P c G$ genes resulting in downregulation of AtMEA, AtFIE and AtFIS2, cause seed-like structure formation in the absence of fertilization and the production of non-viable seeds after fertilization. In both cases endosperm overproliferation has been observed. Endosperm overproliferation could be a desirable feature of viable and qualitatively acceptable seeds in crops where the seed and in particular the endosperm is the agronomically important product. In this study we attempted to analyze quantitatively the expression of the PcG gene homologues in different seed developmental stages and in two barley cultivars differing in seed size, in order to unravel any association between the expression of these genes with seed development and the size of seed. Quantitative real time PCR expression analysis revealed a differential expression pattern during seed development and significant differences between two barley cultivars with varying seed size for the $P c G$ genes. HvFIE exhibits a pronounced increase after fertilization for both cultivars, which declines in Caresse after 3-5 DAF, but increases remarkably in Ippolytos (approximately 7 fold) at 5-10 and 10-15 DAF. Interestingly, HvFIE transcript levels are markedly higher in Ippolytos at 5-10 and 10-15 DAF than in Caresse by approximately a factor of 1.5 and 3.5 , respectively. $H v E(Z)$ expression shows a decline in Caresse seeds 3-15 days after fertilization as compared to flowers prior to fertilization, with a marked 2 fold decrease at 3-5 DAF. Conversely, such a reduction is not observed in Ippolytos, where $H v E(Z)$ transcript levels do not show any significant changes among seed stages. In barley, endosperm cellularization begins at approximately 4 DAF and ends at 6-8 DAF, when the seed maturation process begins [6]. It might be possible that the differences in $H v E(Z)$ and $H v F I E$ expression between the two cultivars during these critical stages of endosperm development are associated with the processes of cellularization and seed filling and ultimately with the size of seed. For $\mathrm{HvSu}(z) 12 b$, transcript levels show an induction after fertilization at 5-10 and 10-15 DAF, implying a role for $\mathrm{H \nu Su}(z) 12 b$ in the cellularization and seed maturation process for both cultivars. Further experiments will be needed to elucidate the precise roles of these $P c G$ genes in barley seed development.

The plant hormone $\mathrm{ABA}$, is involved in various plant developmental processes, including seed development, germination and abiotic stress tolerance. In Arabidopsis, ABA plays a central signalling role during seed filling, interacting with master regulator genes such as $A B I 3$ and FUS3, in a gene activation manner [reviewed in [65]]. Interestingly, FUS3 is one of the targets of both the $A t C L F$ and AtMEA genes (acting in vegetative and reproductive stages, respectively) and it is silenced in leaves and closed flowers [30] where it was also shown to contain the repressive mark H3K27me3. In this work we examined the response of $P c G$ genes to ABA after exogenous $\mathrm{ABA}$ application on seedlings and observed that both $H v E(Z)$ and $H v F I E$ genes are induced by ABA. The observed increase in $H v E(Z)$ and $H v F I E$ expression upon $\mathrm{ABA}$ treatment suggests that these genes might play a role as epigenetic regulators of ABA-mediated processes in seedlings. Chromatin modulators, such as histone deacetylase genes, have been shown previously to be affected by exogenous ABA in Arabidopsis, rice and barley $[35,66,39]$. This is the first time that an induction of $P c G$ genes upon external ABA exposure has been demonstrated. It is possible that the expression of $P c G$ genes is also affected by ABA during seed development, to activate or suppress key regulators, as the cell would require.

\section{Conclusions}

In this work we have presented the identification and characterization of four barley $P c G$ genes, $H v F I E, H v E(Z)$, $\mathrm{HvSu}(z) 12 a$, and $\mathrm{HvSu}(z) 12 b$. All genes were mapped on different barley chromosomes and co-localized with known chromosomal regions responsible for malting quality related traits. Should this be confirmed $P c G$ genes might be used as molecular markers for marker-assisted selection in breeding programmes. Differential expression of $H v F I E, H v E(Z)$, and $H v S u(z) 12 b$ in different seed developmental stages and in two barley cultivars differing 
in seed size, suggested a role for these $P c G$ genes in seed development. In addition $H \nu F I E$ and $H v E(Z)$ were found to be induced by the hormone ABA involved in seed development and stress response. The present work provides a basis for future studies aiming at unraveling the function of barley $P c G$ genes and understanding seed development and stress-response epigenetic regulation in barley and other cereals.

\begin{abstract}
Authors' contributions
AK conceived and designed the experiments, performed the quantitative real time PCR experiments, and wrote the manuscript. DP performed phylogenetic analysis and part of real time PCR experiments and participated in revising the manuscript. AT and EF performed the mapping experiments and participated in the writing of the manuscript. HA performed tissue sampling and qualitative RT-PCR experiments. KB supervised and attended all barley cultivations. MAS designed the mapping experiments and participated in revising the manuscript. AST conceived and directed the whole study, and participated in the writing and revising of the manuscript. All authors read and approved the final manuscript.
\end{abstract}

\section{Acknowledgements}

This work was supported by a PENED grant (O3E $\triangle 402 / 2003)$. Continuous support for the Institute of Agrobiotechnology/CERTH from the General Secretariat of Research and Technology of Greece is also acknowledged. We would also like to thank the three anonymous reviewers for critically improving the manuscript.

\section{Author Details}

IInstitute of Agrobiotechnology, CERTH, Thermi-Thessaloniki, GR-57001, Greece, ${ }^{2}$ CRA-Genomic Research Centre, Fiorenzuola d'Arda, I-29017, Italy, ${ }^{3}$ Department of Agricultural and Food Science, University of Modena and Reggio Emilia, I-42100, Reggio Emilia, Italy, ${ }^{4}$ Cereal Institute, NAGREF, ThermiThessaloniki, GR-57001, Greece and 5Department of Genetics and Plant Breeding, Aristotle University of Thessaloniki, GR-54124, Thessaloniki, Greece

Received: 8 July 2009 Accepted: 21 April 2010

Published: 21 April 2010

\section{References}

1. Goldberg AD, Allis CD, Bernstein E: Epigenetics: a landscape takes shape. Cell 2007, 128:635-38.

2. Wu J, Lessard J, Crabtree GR: Understanding the words of chromatin regulation. Cell 2009, 136:200-206.

3. Chen ZJ, Tian L: Roles of dynamic and reversible histone acetylation in plant development and polyploidy. Biochim Biophys Acta 2007, 1769:295-307

4. Chinnusamy V, Gong Z, Zhu JK: Abscisic acid-mediated epigenetic processes in plant development and stress responses. J Integr Plant Biol 2008, 50:1187-1195.

5. Chinnusamy V, Zhu JK: Epigenetic regulation of stress responses in plants. Curr Opin Plant Biol 2009, 12:133-139.

6. Olsen OA: Nuclear endosperm development in cereals and Arabidopsis thaliana. Plant Cell 2004, 16:S214-S227.

7. Gehring M, Choi Y, Fischer RL: Imprinting and seed development. Plant Cell 2004:S203-13.

8. Huh JH, Bauer MJ, Hsieh TF, Fischer RL: Cellular Programming of Plant Gene Imprinting. Cell 2008, 132:735-744.

9. Guitton AE, Page DR, Chambrier P, Lionnet C, Faure JE, Grossniklaus U, Berger F: Identification of new members of Fertilisation Independent Seed Polycomb Group pathway involved in the control of seed development in Arabidopsis thaliana. Development 2004, 131:2971-2981.

10. Köhler C, Hennig L, Bouveret R, Gheyselinck J, Grossniklaus U, Gruissem W: Arabidopsis MSI1 is a component of the E(Z)/FIE Polycomb group complex and required for seed development. EMBO J 2003, 22:4804-4814.
11. Adams S, Vinkenoog R, Spielman M, Dickinson HG, Scott RJ: Parent-oforigin effects on seed development in Arabidopsis thaliana require DNA methylation. Development 2000, 127:2493-2502.

12. Kinoshita T, Yadegari R, Harada JJ, Goldberg RB, Fischer RL: Imprinting of the MEDEA Polycomb gene in the Arabidopsis endosperm. Plant Cell 1999, 11:1945-1952.

13. Luo M, Bilodeu P, Dennis ES, Peacock JW, Chaudhury AML: Expression and parent-of-origin effects for FIS2, E(Z), and FIE in the endosperm and embryo of developing Arabidopsis seeds. Proc Natl Acad Sci USA 2000, 97:10637-10642.

14. Yadegari R, Kinoshita T, Lotan O, Cohen G, Katz A, Choi Y, Katz A, Nakashima K, Harada JJ, Goldberg RB, Fischer RL, Ohad N: Mutations in the FIE and E(Z) Genes That Encode Interacting Polycomb Proteins Cause Parent-of-Origin Effects on Seed Development by Distinct Mechanisms. Plant Cell 2000, 12:2367-2382.

15. Chanvivattana Y, Bishopp A, Schubert D, Stock C, Moon Y-H, Sung ZR, Goodrich J: Interaction of Polycomb-group proteins controlling flowering in Arabidopsis. Development 2004, 131:5263-5276.

16. Cao R, Zhang Y: The functions of $E(Z) / E Z H 2$-mediated methylation of lysine 27 in histone H3. Curr Opin Genet Dev 2004, 14:155-164.

17. Köhler C, Villar CBR: Programming of gene expression by Polycomb group proteins. Trends Cell Biol 2008, 18:236-243.

18. Schatlowski N, Creasy K, Goodrich J, Schubert D: Keeping plants in shape: Polycomb-group genes and histone methylation. Sem Cell Dev Biol 2008, 19:547-553.

19. Grossniklaus U, Vielle-Cazalda JP, Hoepner MA, Gagliano W: Maternal Control of Embryogenesis by MEDEA, a Polycomb Group Gene in Arabidopsis thaliana. Science 1998, 280:448-449.

20. Ohad N, Yadegari R, Margossian L, Hannon M, Michaeli D, Harada JJ, Goldberg RB, Fischer RL: Mutations in FIE, a WD Polycomb group gene, allow endosperm development without fertilization. Plant Cell 1999, 11:407-416.

21. Schubert D, Primavesi L, Bishopp A, Roberts G, Doonan J, Jenuwein T, Goodrich J: Silencing by plant Polycomb-group genes requires dispersed trimethylation of histone $\mathrm{H} 3$ at lysine 27. EMBO J 2006, 25:4638-4649

22. Sung $S$, Amasino RM: Vernalization in Arabidopsis thaliana is mediated by the PhD finger protein VIN3. Nature 2004, 427:159-164.

23. Wood CC, Robertson M, Tanner G, Peacock WJ, Dennis ES, Helliwell CA The Arabidopsis thaliana vernalization response requires a polycomblike protein complex that also includes VERNALIZATION INSENSITIVE 3. Proc Natl Acad Sci USA 2006, 103:14631-14636.

24. Birve A, Sengupta AK, Beuchle D, Larsson J, Kennison JA, RasmusonLestander A, Müller J: Su(z) 12, a novel Drosophila Polycomb group gene that is conserved in vertebrates and plants. Development 2001, 128:3371-3379.

25. Köhler C, Hennig L, Spillane C, Pien S, Gruissem W, Grossniklaus U: The Polycomb-group protein MEDEA regulates seed development by controlling expression of the MADS-box gene PHERES1. Genes Dev 2003, 17:1540-1553.

26. Köhler C, Hennig L, Page D, Gagliardini V, Gruissem W, Grossniklaus U: The Arabidopsis thaliana MEDEA Polycomb group protein controls expression of PHERES 1 by parental imprinting. Nature Genet 2004 37:28-30.

27. Makarevich G, Villar CBR, Erilova A, Köhler C: Mechanism of PHERES imprinting in Arabidopsis. J Cell Science 2008, 121:906-912.

28. Gehring M, Huh JH, Hsieh TF, Penterman J, Choi Y, Harada JJ, Goldberg RB, Fischer RL: DEMETER DNA glycosylase establishes MEDEA polycomb gene self-imprinting by allele-specific demethylation. Cell 2006, 124:495-506.

29. Jullien PE, Katz A, Oliva M, Ohad N, Berger F: Polycomb Group complexes self-regulate imprinting of the Polycomb Group gene MEDEA in Arabidopsis. Curr Biol 2006, 16:486-492.

30. Makarevich G, Leroy O, Akinci U, Schubert D, Clarenz O, Goodrich J, Grossniklaus U, Köhler C: Different. Polycomb group complexes regulate common target genes in Arabidopsis. EMBO Rep 2006, 7:947-952.

31. Finkelstein RR, Gampala SS, Rock CD: Abscisic acid signalling in seeds and seedlings. Plant Cell 2002, 14:S15-S45

32. Nambara E, Marion-Poll A: Abscisic acid biosynthesis and catabolism. Annu Rev Plant Biol 2005, 56:165-185. 
33. Ng DWK, Chandrasekharan MB, Hall TC: Ordered histone modifications are associated with transcriptional poising and activation of the phaseolin promoter. Plant Cell 2006, 18:119-132.

34. Perruc E, Kinoshita N, Lopez-Molina L: The role of chromatin-remodeling factor PKL in balancing osmotic stress responses during Arabidopsis seed germination. Plant J 2007, 52:927-936.

35. Sridha S, Wu K: Identification of AtHD2C as a novel regulator of abscisic acid responses in Arabidopsis. Plant $J$ 2006, 46:124-133.

36. Saez A, Rodrigues A, Santiago J, Rubio S, Rodriguez PL: HAB1-SWI3B interaction reveals a link between abscisic acid signaling and putative SWI/SNF chromatin-remodeling complexes in Arabidopsis. Plant Cell 2008, 20:2972-88

37. Yin H, Zhang X, Liu J, Wang Y, He J, Yang T, Hong X, Yang Q, Gong Z Epigenetic regulation, somatic homologous recombination, and abscisic acid signaling are influenced by DNA polymerase epsilon mutation in Arabidopsis. Plant Cell 2009, 21:386-402.

38. Sreenivasulu N, Usadel B, Winter A, Radchuk V, Scholz U, Stein N, Weschke W, Strickert M, Close TJ, Stittt M, Graner A, Wobus U: Barley grain maturation and germination: metabolic pathway and regulatory network commonalities and differences highlighted by new MapMan/ PageMan profiling tools. Plant Phys 2008, 146:1738-1758.

39. Demetriou K, Kapazolgou A, Tondelli A, Francia E, Stanca MS, Bladenopoulos K, Tsaftaris AS: Epigenetic chromatin modifiers in barley: I. Cloning, mapping and expression analysis of the plant specific HD2 family of histone deacetylases from barley, during seed development and after hormonal treatment. Physiol Plant 2009, 136:358-368.

40. Demetriou K, Kapazolgou A, Bladenopoulos K, Tsaftaris AS: Epigenetic chromatin modifiers in barley: II. Characterization and expression analysis of the HDA1 family of barley histone deacetylases during development and in response to jasmonic acid. Plant Mol Biol Rep 2010, 28:9-21

41. Papaefthimiou D, Likotrafiti E, Kapazoglou A, Bladenopoulos K, Tsaftaris A: Epigenetic chromatin modifiers in barley: III. Isolation and characterization of the barley GNAT-MYST family of histone acetyltransferases and responses to exogenous ABA. Plant Physiol Biochem 2010, 48:98-107.

42. Altschul SF, Gish W, Miller W, Myers EW, Lippman DJ: Basic Local Alignment Search Tool. J Mol Biol 1993, 215:403-410.

43. Thomson JD, Higgins DG, Gibson TJ: ClustalW: improving the sensitivity of progressive multiple sequence alignment through sequence weighting, position-specific gap penalties and weight matrix choice. Nucl Acids Res 1994, 22:4673-80.

44. Kumar S, Tamura K, Nei M: MEGA3: Integrated software for Molecular Evolutionary Genetics Analysis and sequence alignment. Briefings in Bioinformatics 2004, 5:150-63.

45. Saitou N, Nei M: The neighbor-joining method: a new method for reconstructing phylogenetic trees. Mol Biol 1987, E 4:406-25

46. Ronquist F, Huelsenbeck JP: MRBAYES 3: Bayesian phylogenetic inference under mixed models. Bioinformatics 2003, 19:1572-1574.

47. Page RDM: TreeView: An application to display phylogenetic trees on personal computers. Computer Applications in the Biosciences 1996 12:357-358

48. Costa MJ, Corey A, Hayes PM, Jobet C, Kleinhofs A, Kopisch-Obusch A, Kramer SF, Kudrna D, Li M, Riera-Lizarazu O, Sato K, Szucs P, Toojinda T, Vales MI, Wolfe RI: Molecular mapping of the Oregon Wolfe Barleys: a phenotypically polymorphic doubled-haploid population. Theor App Genet 2001, 103:415-24

49. Marcel TC, Varshney RK, Barbieri M, Jafary H, de Kock MJD, Graner A, Niks RE: A high-density consensus map of barley to compare the distribution of QTLs of partial resistance to Puccinia hordei and of defense gene homologues. Theor Appl Genet 2007, 114:487-500.

50. Rozen S, Skaletsky H: Primer3 on the WWW for general users and for biologist programmers. Meth Mol Biol 2000, 132:365-86.

51. Neff MM, Neff JD, Chory J, Pepper AE: dCAPS, a simple technique for genetic analysis of single nucleotide polymorphisms: experimental applications in Arabidopsis thaliana genetics. Plant J 1998, 14:387-392.

52. Van Ooijen JW: Joinmap": Software for the calculation of genetic linkage maps in experimental populations Version 4. Wageningen (The Netherlands): Kyazma BV; 2006

53. Szücs P, Blake VC, Bhat PR, Chao S, Close TJ, Cuesta-Marcos A, Muehlbauer GJ, Ramsay L, Waugh R, Hayes PM: An Integrated Resource for Barley
Linkage Map and Malting Quality QTL Alignment. Plant Genome 2008, 2:134-140.

54. Pfaffl MW, Horgan GW, Dempfle L: Relative expression software tool (REST) for group-wise comparison and statistical analysis of relative expression results in real-time PCR. Nucleic Acids Res 2002, 30:e36.

55. Shen Q, Chen CN, Brands A, Pan SM, Ho TH: The stress- and abscisic acidinduced barley gene HVA22: developmental regulation and homologues in diverse organisms. Plant Mol 2001, 45:327-340

56. Wang D, Tyson MD, Jackson SS, Yadegari R: Partially redundant functions of two SET-domain polycomb-group proteins in controlling initiation of seed development in Arabidopsis. Proc Natl Acad Sci 2006, 103:13244-13249

57. Spillane C, Schmid KJ, Laoueille-Duprat S, Pien S, Escobar-Restrepo JM, Baroux C, Gagliardini V, Page DR, Wolfe KH, Grossniklaus U: Positive darwinian selection at the imprinted MEDEA locus in plants. Nature 2007, 448:349-352.

58. Springer NM, Danilevskaya ON, Hermon P, Helentjaris TG, Phillips RL, Kaeppler HF, Kaeppler SM: Sequence relationships, conserved domains and expression patterns for maize homologs of the polycomb group genes $E(z)$, esc and $E(P C)$. Plant Physiol 2002, 128:1332-1345.

59. Thakur J, Malik MP, Bhatt V, Reddy M, Sopory S, Tyagi AK, Khurana J: A POLYCOMB group gene of rice (Oryza sativa $L$ subspecies indica) OsiEZ1, codes for a nuclear-localized protein expressed preferentially in young shoots and during reproductive development. Gene 2003, 313:1-13

60. Luo M, Platten D, Chaudhury A, Peacock WJ, Dennis ES: Expression, imprinting, and evolution of rice homologues of the Polycomb group genes. Molecular Plant 2009, 2:711-723.

61. Fox GP, Panozzo JF, Li CD, Lance RCM, Henry RJ: Molecular basis of barley quality. Aust J 2003, 54:1081-1101

62. Spillane C, MacDougall C, Stock C, Köhler C, Vielle-Gazalda JP, Nunes SM, Grossniklaus U, Goodrich J: Interaction of the Arabidopsis Polycomb group proteins FIE and $\mathrm{E}(\mathrm{Z})$ mediates their common phenotypes. Curr Biol 2000, 10:1535-1538

63. Danilevskaya ON, Hermon P, Hantke S, Muszynski MG, Kollipara K, Ananiev EV: Duplicated FIE genes in maize: expression pattern and imprinting suggest distinct functions. Plant Cell 2003, 15:425-438

64. Kiyosue T, Ohad N, Yadegari R, Hannon M, Dinneny J, Wells D, Katz A Margossian L, Harada JJ, Goldberg RB, Fisher RL: Control of fertilization independent endosperm development by the MEDEA polycomb gene in Arabidopsis. Proc Natl Acad Sci USA 1999, 96:4186-4191.

65. Verdier J, Thompson RD: Transcriptional regulation of storage protein synthesis during dicotyledon seed filling. Plant Cell Physiol 2008, 49:1263-71.

66. Fu W, Wu K, Duan J: Sequence and expression analysis of histone deacetylases in rice. Biochem Biophys Res Comm 2007, 356:843-850

doi: 10.1186/1471-2229-10-73

Cite this article as: Kapazoglou et al., Epigenetic chromatin modifiers in barley: IV. The study of barley Polycomb group (PCG) genes during seed development and in response to external ABA BMC Plant Biology 2010, 10:73

\section{Submit your next manuscript to BioMed Centra and take full advantage of:}

- Convenient online submission

- Thorough peer review

- No space constraints or color figure charges

- Immediate publication on acceptance

- Inclusion in PubMed, CAS, Scopus and Google Scholar

- Research which is freely available for redistribution 